Review

\title{
Anti-COVID-19 Vaccination in Patients with Autoimmune-Autoinflammatory Disorders and Primary/Secondary Immunodeficiencies: The Position of the Task Force on Behalf of the Italian Immunological Societies
}

\author{
Raffaele D'Amelio ${ }^{1,+}{ }^{(D}$, Riccardo Asero ${ }^{2}$, Marco Antonio Cassatella ${ }^{3}$, Bruno Laganà ${ }^{4}$, Claudio Lunardi ${ }^{5}$, \\ Paola Migliorini ${ }^{6}$, Roberto Nisini ${ }^{7}$, Paola Parronchi ${ }^{8} \mathbb{D}$, Isabella Quinti ${ }^{9}$, Vito Racanelli ${ }^{10} \mathbb{D}_{\text {, Gianenrico Senna }}{ }^{11}$, \\ Angelo Vacca ${ }^{12}$ (D) and Enrico Maggi ${ }^{13, *(D)}$
}

check for

updates

Citation: D'Amelio, R.; Asero, R.; Cassatella, M.A.; Laganà, B.; Lunardi, C.; Migliorini, P.; Nisini, R.; Parronchi, P.; Quinti, I.; Racanelli, V.; et al. Anti-COVID-19 Vaccination in Patients with

Autoimmune-Autoinflammatory Disorders and Primary/Secondary Immunodeficiencies: The Position of the Task Force on Behalf of the Italian Immunological Societies. Biomedicines 2021, 9, 1163. https://doi.org/ 10.3390 /biomedicines 9091163

Academic Editor: Anand

Prakash Singh

Received: 23 July 2021

Accepted: 1 September 2021

Published: 4 September 2021

Publisher's Note: MDPI stays neutral with regard to jurisdictional claims in published maps and institutional affiliations.

Copyright: (c) 2021 by the authors. Licensee MDPI, Basel, Switzerland. This article is an open access article distributed under the terms and conditions of the Creative Commons Attribution (CC BY) license (https:/ / creativecommons.org/licenses/by/ $4.0 /)$
1 Dipartimento di Medicina Clinica e Molecolare, Sapienza Università di Roma, Via di Grottarossa 1035-1039, 00189 Rome, Italy; raffaele.damelio@uniroma1.it

2 Ambulatorio di Allergologia, Clinica S. Carlo di Paderno Dugnano, Via Ospedale 21, 20037 Milano, Italy; r.asero@libero.it

3 Sezione di Patologia Generale, Dipartimento di Medicina, Università di Verona, Strada Le Grazie 4, 37134 Verona, Italy; marco.cassatella@univr.it

4 UOC Medicina Interna, Dipartimento di Medicina Clinica e Molecolare, AOU S. Andrea, Sapienza Università di Roma, Via di Grottarossa 1035-1039, 00189 Rome, Italy; bruno.lagana@ospedalesantandrea.it

5 Responsabile Unità di Malattie Autoimmunitarie, Dipartimento di Medicina, AOU Policlinico G.B. Rossi, Borgo Roma, Università di Verona, Piazzale Ludovico Antonio Scuro 10, 37134 Verona, Italy; claudio.lunardi@univr.it

6 Direttore Unità Operativa di Immunoallergologia Clinica, Dipartimento di Medicina Clinica e Sperimentale, Azienda Ospedaliero Universitaria Pisana, Università di Pisa, Via Roma 67, 56126 Pisa, Italy; paola.migliorini@med.unipi.it

7 Direttore Reparto Immunologia, Dipartimento di Malattie Infettive, Istituto Superiore di Sanità, Viale Regina Elena 299, 00161 Rome, Italy; roberto.nisini@iss.it

8 Direttore SOD Immunologia e Terapie Cellulari, Dipartimento di Medicina Sperimentale e Clinica, AOU Careggi, Università di Firenze, Largo Brambilla 3, 50134 Firenze, Italy; paola.parronchi@unifi.it

9 Responsabile UOD Centro di Riferimento Regionale per le Immunodeficienze, Dipartimento di Medicina Molecolare, AOU Policlinico Umberto I, Sapienza Università di Roma, Viale dell'Università 37, 00161 Rome, Italy; isabella.quinti@uniroma1.it

10 UOC Medicina Interna "Guido Baccelli", Dipartimento di Scienze Biomediche ed Oncologia Umana, AOU Policlinico, Università di Bari, Piazza Giulio Cesare 11, 70124 Bari, Italy; vito.racanelli1@uniba.it

11 Direttore USD Allergologia, Dipartimento di Medicina, AOU Policlinico G.B. Rossi, Borgo Roma, Università di Verona, Piazzale Ludovico Antonio Scuro 10, 37134 Verona, Italy; gianenrico.senna@aovr.veneto.it

12 Direttore UOC Medicina Interna "Guido Baccelli", Dipartimento di Scienze Biomediche ed Oncologia Umana, AOU Policlinico, Università di Bari, Piazza Giulio Cesare 11, 70124 Bari, Italy; angelo.vacca@uniba.it

13 Unità di Immunità Traslazionale, Dipartimento di Immunologia, Ospedale Pediatrico Bambino Gesù, IRCCS, Viale di S. Paolo 15, 00146 Rome, Italy

* Correspondence: enrico.maggi@opbg.net + Retired.

Abstract: The Coronavirus disease 2019 (COVID-19) pandemic has represented an unprecedented challenge for humankind from health, economic, and social viewpoints. In February 2020, Italy was the first western country to be deeply hit by the pandemic and suffered the highest case/fatality rate among western countries. Brand new anti-COVID-19 vaccines have been developed and made available in $<1$-year from the viral sequence publication. Patients with compromised immune systems, such as autoimmune-autoinflammatory disorders (AIAIDs), primary (PIDs) and secondary (SIDs) immunodeficiencies, have received careful attention for a long time regarding their capacity to safely respond to traditional vaccines. The Italian Immunological Societies, therefore, have promptly faced the issues of safety, immunogenicity, and efficacy/effectiveness of the innovative COVID-19 vaccines, as well as priority to vaccine access, in patients with AIADs, PIDs, and SIDs, by organizing an ad-hoc Task Force. Patients with AIADs, PIDs, and SIDs: (1) Do not present contraindications 
to COVID-19 vaccines if a mRNA vaccine is used and administered in a stabilized disease phase without active infection. (2) Should usually not discontinue immunosuppressive therapy, which may be modulated depending on the patient's clinical condition. (3) When eligible, should have a priority access to vaccination. In fact, immunizing these patients may have relevant social/health consequences, since these patients, if infected, may develop chronic infection, which prolongs viral spread and facilitates the emergence of viral variants.

Keywords: COVID-19; SARS-CoV-2; vaccines; auto-immune auto-inflammatory disorders; primary immunodeficiencies; secondary immunodeficiencies

\section{Introduction}

The Coronavirus disease 2019 (COVID-19) pandemic as of 10 July 2021 has globally caused 186,152,198 cases and 4,021,065 deaths, whereas 3,393,833,500 anti-COVID-19 vaccine doses have been administered (https:/ / coronavirus.jhu.edu/map.html, accessed on 22 July 2021). In February 2020, Italy was the first western country to be deeply hit by the pandemic, which developed in at least three consecutive waves, the first in the first half of 2020, the second and the third between the last trimester of 2020 and the first half of 2021. One characteristic of Italy has been, since the beginning, a high case/fatality rate. In fact, according to Johns Hopkins University, Italy at the global level ranks 10th for number of cases, after USA, India, Brazil, France, Russia, Turkey, UK, Argentina, and Colombia, but among these countries, Italy shows the highest case/fatality rate of $2.99 \%$. The high number of cases and the high lethality, the first among western countries, prompted the three Italian Immunological Societies (Associazione Allergologi ed Immunologi Italiani Territoriali ed Ospedalieri [AAIITO], Società Italiana di Allergologia, Asma ed Immunologia Clinica [SIAAIC], Società Italiana di Immunologia, Immunologia Clinica e Allergologia [SIICA]), as soon as anti-COVID-19 vaccines became available, to set up a Task Force, including immunologists and clinical immunologists, to draw up guidelines on COVID-19 vaccination in vulnerable patients with diseases of the immune system, such as autoimmune-autoinflammatory disorders (AIAIDs), as well as primary (PIDs) and secondary (SIDs) immune deficiency diseases. In particular, the Task Force has faced the following issues: (1) analyzing the different anti-COVID-19 vaccine types in order to identify possible contraindications of specific vaccines in these patients; (2) establishing the compatibility of the different diseases of the immune system with these innovative vaccines; (3) evaluating the possible interference of the different therapies with the vaccines and the consequent possible interruption or modification of the doses of these therapies; (4) identifying criteria to fix priority levels in the access to vaccination, based on the major risk of infection and disease severity.

Vaccinations are a safe and effective tool for prevention and control of infectious diseases, particularly in patients with AIAIDs, PIDs, and SIDs. In fact, these patients have a higher infection risk, thus safety, immunogenicity, and efficacy of traditional vaccines, as well as possible vaccine contraindications, has been widely and thoroughly studied [1-15] (Tables 1-3) Therefore, the Task Force adopted the method of carefully analyzing the literature, to examine the response of the different pathologies of the immune system to the traditional vaccines, as the basis for inferring possible reactions of these pathologies challenged with the innovative anti-COVID-19 vaccines [1-15] Tables 1-3 The Task Force worked by teleconference for a total of six meetings during the period of March-May 2021. 
Table 1. Inactivated and live traditional vaccines (not anti-COVID-19) in patients with AIAIDs and influence of the relative therapies.

\begin{tabular}{|c|c|c|c|c|c|}
\hline AIAIDs & Corticosteroids & IVIg/scDMARDs & $\begin{array}{l}\text { bDMARDs/ } \\
\text { tsDMARDs }\end{array}$ & $\begin{array}{c}\text { Inactivated } \\
\text { Vaccines }\end{array}$ & Live Vaccines \\
\hline & $\begin{array}{c}\text { High doses: } \geq 20 \\
\text { mg/day } \\
\text { prednisone- } \\
\text { equivalent for } 1-2 \\
\text { weeks; non im- } \\
\text { munosuppressive } \\
\text { doses: } 7.5 \mathrm{mg} \text { / day }\end{array}$ & $\begin{array}{l}\text { Sulphasalazine, hy- } \\
\text { droxichloroquine, } \\
\text { azathioprine, } \\
\text { mycophenolate, } \\
\text { methotrexate, } \\
\text { leflunomide, } \\
\text { cyclosporine, } \\
\text { tacrolimus, } \\
\text { cyclophosphamide }\end{array}$ & $\begin{array}{c}\text { infliximab, } \\
\text { adalimumab, } \\
\text { etanercept, } \\
\text { golimumab, } \\
\text { certolizumab, } \\
\text { rituximab, } \\
\text { tocilizumab, } \\
\text { abatacept, } \\
\text { anakinra, } \\
\text { canakinumab, } \\
\text { belimumab, } \\
\text { secukinumab, } \\
\text { ixekizumab, } \\
\text { ustekinumab, } \\
\text { tofacitinib, } \\
\text { baricitinib }\end{array}$ & $\begin{array}{c}\text { Hepatitis A/B, } \\
\text { human } \\
\text { papillomavirus, } \\
\text { influenza, herpes } \\
\text { zoster, inactivated } \\
\text { poliovirus, } \\
\text { pneumococcus, } \\
\text { tetanus/diphtheria/ } \\
\text { pertussis, } \\
\text { polysaccharide } \\
\text { typhoid fever, Hib, } \\
\text { meningococcus }\end{array}$ & $\begin{array}{c}\text { Measles/Mumps/ } \\
\text { Rubella, Varicella, } \\
\text { BCG, Ty21A, } \\
\text { Yellow fever }\end{array}$ \\
\hline $\begin{array}{c}\text { Rheumatoid } \\
\text { arthritis, Systemic } \\
\text { lupus, } \\
\text { erythematosus } \\
\text { Sjögren Syndrome, } \\
\text { Anti-phospholipid } \\
\text { syndrome, } \\
\text { Systemic sclerosis, } \\
\text { Polymyositis/ } \\
\text { dermatomyositis, } \\
\text { Vasculitis, } \\
\text { Psoriatic arthritis, } \\
\text { Spondyloarthritis, } \\
\text { Familiar } \\
\text { Mediterranean } \\
\text { Fever, } \\
\text { Periodical fever } \\
\text { syndromes, } \\
\text { Type } 1 \text { diabetes, } \\
\text { Inflammatory } \\
\text { bowel diseases, } \\
\text { Multiple sclerosis }\end{array}$ & $\begin{array}{l}\text { At high doses, they } \\
\text { seem to interfere } \\
\text { with the immune } \\
\text { response to } \\
\text { vaccines. } \\
\text { Combination } \\
\text { steroids/anti-TNF- } \\
\alpha \text { is particularly } \\
\text { associated with the } \\
\text { infection risk [10]. }\end{array}$ & $\begin{array}{l}\text { IVIg should not be } \\
\text { administered } \\
\text { together with live } \\
\text { vaccines due to the } \\
\text { risk of vaccine } \\
\text { inactivation [11], } \\
\text { or with an } \\
\text { inactivated vaccine } \\
\text { because evaluating } \\
\text { vaccine } \\
\text { immunogenicity } \\
\text { become } \\
\text { simpossible. } \\
\text { csDAMRDs are } \\
\text { generally well } \\
\text { tolerated at the } \\
\text { doses generally } \\
\text { used in IMIDs and } \\
\text { they do not seem } \\
\text { to interfere with } \\
\text { the immune } \\
\text { response. For } \\
\text { methotrexate, a } \\
\text { negative } \\
\text { interference with } \\
\text { the pneumococcal } \\
\text { vaccine has been } \\
\text { described, which } \\
\text { has not been } \\
\text { confirmed with the } \\
\text { conjugate vaccine } \\
\text { [12]. }\end{array}$ & $\begin{array}{l}\text { When used alone, } \\
\text { they are well } \\
\text { tolerated and do } \\
\text { not induce im- } \\
\text { munosuppression; } \\
\text { immunosuppres- } \\
\text { sion is induced } \\
\text { when they are used } \\
\text { in combination. } \\
\text { Abatacept and } \\
\text { tofacitinib have } \\
\text { been associated } \\
\text { with a slightly } \\
\text { reduced response } \\
\text { to influenza and } \\
\text { pneumococcus } \\
\text { vaccines. } \\
\text { Rituximab } \\
\text { markedly reduces } \\
\text { antibody response, } \\
\text { but it does not } \\
\text { seem to modify the } \\
\text { adaptive cellular } \\
\text { one [13]. } \\
\text { Vaccination should } \\
\text { be carried out } \\
\text { before starting } \\
\text { therapy with } \\
\text { rituximab; in case } \\
\text { of impossibility, it } \\
\text { should be carried } \\
\text { out } 6 \text { months after } \\
\text { the last infusion of } \\
\text { rituximab and } 1 \\
\text { month before the } \\
\text { next one. }\end{array}$ & $\begin{array}{l}\text { Generally allowed, } \\
\text { influenza and } \\
\text { pneumococcus } \\
\text { recommended, } \\
\text { and, in particular } \\
\text { subjects, hepatitis } \\
\text { B, papillomavirus } \\
\text { and herpes zoster. }\end{array}$ & $\begin{array}{c}\text { Generally } \\
\text { contraindicated, } \\
\text { Measles/Mumps/ } \\
\text { Rubella seems well } \\
\text { tolerated. Caution } \\
\text { for Yellow fever, } \\
\text { even though a } \\
\text { recent review } \\
\text { seems to partially } \\
\text { reduce these fears } \\
\text { [14]. }\end{array}$ \\
\hline
\end{tabular}

AIAIDs = Autoimmune-autoinflammatory disorders; IMIDs = Immune-Mediated Inflammatory Disorder(s); IVIg = Intravenous immunoglobulin; scDMARDs = Synthetic conventional Disease-Modifying Anti-Rheumatic Drugs; bDMARDS = Biologic Disease-Modifying Anti-Rheumatic Drugs; tsDMARDs = Targeted synthetic Disease-Modifying Anti-Rheumatic Drugs; Hib = Haemophilus influenzae b, $\mathrm{BCG}=$ Bacillus Calmette-Guérin; Ty21A = oral live vaccine for typhoid fever. 
Table 2. Inactivated and live traditional vaccines (not anti-COVID-19) in patients with PIDs and influence of the relative therapies.

\begin{tabular}{|c|c|c|c|c|c|}
\hline PIDs & Corticosteroids & IVIg/SCIg & $\begin{array}{c}\text { HSCT/Gene } \\
\text { therapy }\end{array}$ & $\begin{array}{l}\text { Inactivated } \\
\text { Vaccines }\end{array}$ & Live Vaccines \\
\hline & $\begin{array}{l}\text { High doses: } \geq 20 \\
\text { mg/day } \\
\text { prednisone- } \\
\text { equivalent for } 1-2 \\
\text { weeks; non im- } \\
\text { munosuppressive } \\
\text { doses: } 7.5 \mathrm{mg} / \text { day }\end{array}$ & & & $\begin{array}{c}\text { Hepatitis A/B, } \\
\text { human } \\
\text { papillomavirus, } \\
\text { influenza, herpes } \\
\text { zoster, inactivated } \\
\text { poliovirus, } \\
\text { pneumococcus, } \\
\text { tetanus/diphtheria/ } \\
\text { pertussis, } \\
\text { polysaccharide } \\
\text { typhoid fever, Hib, } \\
\text { meningococcus, }\end{array}$ & $\begin{array}{c}\text { Measles/Mumps/ } \\
\text { Rubella, Varicella, } \\
\text { BCG, Ty21A, } \\
\text { Yellow fever }\end{array}$ \\
\hline
\end{tabular}

\section{Major antibody \\ defects (XLA, \\ CVID)}

Minor antibody

defects (Defect of:

$$
\operatorname{IgA}, \operatorname{IgG}
$$

subclasses, specific

antibodies)

SCID-CID

MSMD

Invasive bacterial infections

CMCD

Defects of TLR

Defects of

IL12/IFN-

spathway

Defects of

complement

Congenital

phagocyte defects

Complete

DiGeorge

Syndrome

Partial DiGeorge

Syndrome

Ataxia-

Telangiectasia

Wiskott-Aldrich

Syndrome

Hyper-IgE

Syndrome

IPEX Syndrome

APECED

Syndrome
At high doses, they seem to interfere with the immune response to vaccines.

\author{
IVIg should not be \\ administered \\ together with live \\ vaccines due to the \\ risk of vaccine \\ inactivation [11], \\ or with an \\ inactivated vaccine \\ because evaluating \\ vaccine \\ immunogenicity \\ becomes \\ impossible.
}

After 1 year
following
engraftment and
lack of GVHD, it is
possible to set the
vaccination
schedule with
inactivated
vaccines. Live
vaccines should
not be set before 2
years from
transplant [15].

Generally allowed in all the PIDs, excepting SCID and complete DiGeorge syndrome, in which only the polysaccharide vaccines (meningococcus, pneumococcus, Hib) are allowed.
Generally contraindicated, MMR and Varicella seem well tolerated in the minor antibody defects, complement defects, congenital phagocyte defects, partial DiGeorge syndrome, ataxiatelangiectasia, and hyper-IgE syndrome. Caution should be used for Yellow fever vaccine.

PIDs = Primary immunodeficiencies; IVIg = Intravenous immunoglobulin; SCIg = Subcutaneous immunoglobulin BCG = Bacillus Calmette-Guérin; Ty21A = oral live vaccine for typhoid fever; HSCT = Hematopoietic Stem-Cell Transplantation; XLA = X-linked agammaglobulinemia; CVID = Common variable immunodeficiency; SCID = Severe combined immunodeficiency; CID = Combined immunodeficiency; $\mathrm{MSMD}=$ Mendelian susceptibility to mycobacterial disease; $\mathrm{CMCD}=$ Chronic mucocutaneous candidiasis disease; TLR = Toll-like receptors; GVHD = Graft versus host disease; Hib = Haemophilus influenzae type b; IPEX = Immune dysregulation, poly-endocrinopathy, enteropathy X-linked; APECED = Autoimmune poly-endocrinopathy-candidiasis-ectoderma-dystrophy. 
Table 3. Inactivated and live traditional vaccines (not anti-COVID-19) in patients with SIDs and influence of the relative therapies.

\begin{tabular}{|c|c|c|c|c|c|}
\hline SIDs & Corticosteroids & IVIg/SCIg & $\begin{array}{l}\text { Chemotherapy/ } \\
\text { Biologics/Janus } \\
\text { Kinase Inhibitors }\end{array}$ & $\begin{array}{l}\text { Inactivated } \\
\text { Vaccines }\end{array}$ & Live Vaccines \\
\hline & $\begin{array}{c}\text { High doses: } \geq 20 \\
\text { mg/day } \\
\text { prednisone- } \\
\text { equivalent for } 1-2 \\
\text { weeks; non im- } \\
\text { munosuppressive } \\
\text { doses: } 7.5 \mathrm{mg} / \text { day }\end{array}$ & & & $\begin{array}{c}\text { Hepatitis A/B, } \\
\text { human } \\
\text { papillomavirus, } \\
\text { influenza, herpes } \\
\text { zoster, inactivated } \\
\text { poliovirus, } \\
\text { pneumococcus, } \\
\text { tetanus/diphtheria/ } \\
\text { pertussis, } \\
\text { polysaccharide } \\
\text { typhoid fever, Hib, } \\
\text { meningococcus }\end{array}$ & $\begin{array}{c}\text { Measles/Mumps / } \\
\text { Rubella, Varicella, } \\
\text { BCG, Ty21A, } \\
\text { Yellow fever }\end{array}$ \\
\hline $\begin{array}{c}\text { Transplanted } \\
\text { patients } \\
\text { Hematological } \\
\text { patients } \\
\text { Oncological } \\
\text { patients } \\
\text { Patients with } \\
\text { IMIDs on immuno- } \\
\text { suppression } \\
\text { Dialysis } \\
\text { patientsSevere } \\
\text { asthma/COPD } \\
\text { Splenectomized } \\
\text { patients } \\
\text { HIV-infected } \\
\text { patients }\end{array}$ & $\begin{array}{l}\text { At high doses they } \\
\text { seem to interfere } \\
\text { with the immune } \\
\text { response to } \\
\text { vaccines. }\end{array}$ & $\begin{array}{l}\text { IVIg should } \\
\text { not be } \\
\text { administered } \\
\text { together with } \\
\text { live vaccines } \\
\text { due to the risk } \\
\text { of vaccine } \\
\text { inactivation } \\
\text { [11], or with an } \\
\text { inactivated } \\
\text { vaccine } \\
\text { because } \\
\text { evaluating } \\
\text { vaccine im- } \\
\text { munogenicity } \\
\text { becomes } \\
\text { impossible. }\end{array}$ & $\begin{array}{l}\text { In case of high-level } \\
\text { immunosuppression } \\
\text { by chemotherapy in } \\
\text { onco-hematological } \\
\text { pathologies, } \\
\text { inactivated vaccines } \\
\text { should preferably be } \\
\text { administered either } \\
\text { before or after, but not } \\
\text { during, the treatment. }\end{array}$ & $\begin{array}{l}\text { Generally allowed } \\
\text { in all the reported } \\
\text { SIDs. } \\
\text { Polysaccharide } \\
\text { vaccines } \\
\text { (pneumococcus, } \\
\text { meningococcus, } \\
\text { Hib) are } \\
\text { specifically } \\
\text { recommended in } \\
\text { the splenectomized } \\
\text { patients. } \\
\text { Polysaccharide } \\
\text { and influenza } \\
\text { vaccines are } \\
\text { recommended in } \\
\text { transplanted } \\
\text { patients and in the } \\
\text { other SIDs. } \\
\text { Hepatitis A and B } \\
\text { in liver } \\
\text { transplanted } \\
\text { patients. Hepatitis } \\
\text { B in HIV-infected } \\
\text { patients. Two } \\
\text { months after the } \\
\text { transplant it is } \\
\text { possible to plan } \\
\text { vaccinations with } \\
\text { inactivated } \\
\text { vaccines [7]. In } \\
\text { Rituximab-treated } \\
\text { patients, } \\
\text { vaccination should } \\
\text { be carried out at } \\
\text { least } 6 \text { months } \\
\text { after the last } \\
\text { infusion. }\end{array}$ & $\begin{array}{c}\text { Generally } \\
\text { contraindicated, } \\
\text { Measles/Mumps / } \\
\text { Rubella and } \\
\text { Varicella are } \\
\text { allowed in } \\
\text { HIV-infected } \\
\text { patients, provided } \\
\text { that they have CD4 } \\
\geq 200 / \mu \text { L. } \\
\text { Caution for Yellow } \\
\text { fever, even though } \\
\text { a recent review } \\
\text { seems to partially } \\
\text { reduce } \\
\text { these fears [14]. }\end{array}$ \\
\hline
\end{tabular}

SIDs = Secondary immunodeficiencies; IMIDs = Immune-Mediated Inflammatory Disorder(s); IVIg = Intravenous immunoglobulin; SCIg = Subcutaneous immunoglobulin; Hib = Haemophilus influenzae type b; BCG = Bacillus Calmette-Guérin; Ty21A = oral live vaccine for typhoid fever. 


\section{COVID-19 Vaccines}

The anti-COVID-19 vaccine development has resulted in an unprecedented global effort, which has allowed the first vaccine to be approved for human use less than one year after the publication of the SARS-CoV-2 spike protein-coding sequence on 10 January 2020 [16]. As of 12 June 2021, 287 COVID-19 vaccines are under development, 102 of which are in clinical trials (32 protein subunits, 16 viral vector non-replicating, 16 inactivated viruses, 16 messenger RNA (mRNA), 10 DNA, 5 virus-like particles, 2 viral vectors replicating, 2 viral vector replicating + antigen presenting cells, 2 live attenuated viruses and 1 viral vector non-replicating + antigen presenting cell), and the remaining 185 are in the pre-clinical phase. Of the former 102, six are already approved for human use (two mRNA vaccines, three viral vector non-replicating vaccines and one inactivated vaccine, Table 2), whereas another 15 are in phase 3 of study, including six inactivated virus vaccines, five protein subunits, two mRNA, one DNA and one viral vector non-replicating. The latter, corresponding to the Russian vaccine from Gamaleya Research Institute, has been already used in humans for many months, as approved by the Russian Ministry of Health, but is still reported in the WHO document as phase 3 [17]. The same is true for BBV152 inactivated vaccine, from Bharat Biotech, which has been approved and used in India [18].

Anti-COVID-19 vaccines of the traditional type that are composed of inactivated virus or recombinant Spike protein and adjuvant [19], for which wider scientific knowledge and clinical experience are available, could preferentially be indicated in patients with AIAIDs, PIDs, and SIDs. However, despite demonstrated efficacy for the NVX-CoV2373 of $89.7 \%$ [20], no traditional vaccines are approved by the European Medicines Agency (EMA) yet (Table 4.)

Anti-COVID-19 vaccines based on non-replicating viral vectors, such as those from AstraZeneca (Vaxzevria) [21,22], Janssen/Johnson \& Johnson [23,24], Cansino Biological Inc. [25], and Gamaleya Research Institute [26,27] (Table 4.). are being used for mass vaccination (only the first two vaccines are currently used in Italy). They harness the technology already applied to the anti-Ebola vaccine. AstraZeneca uses an adenovirus from the chimpanzee as a viral vector, Janssen/Johnson \& Johnson uses the human adenovirus 26, Cansino Biological Inc. uses the human adenovirus 5, whereas Gamaleya uses two recombinant human adenoviruses: adenovirus 26 for the first dose and adenovirus 5 for the second dose. One concern of these types of vaccines is the previous and effective anti-viral vector immune response, which may fully inactivate the vaccine; however, this problem involves the general population, not only patients with AIAIDs, PIDs, and SIDs, and may be reduced by using viral vectors from primates. The post-vaccine protection is complete 1-2 weeks following the end of vaccination schedule. In the case of Vaxzevria, protection from severe diseases has been calculated at approximately $70 \%$ after the second of two doses, whereas for the Janssen/Johnson \& Johnson vaccine it has been observed that vaccinated people were protected at $73 \%$ and $82 \%$ at 14 and 28 days, respectively, from the single dose administration [24]. During the registration studies, substantial safety of these vaccines was observed [21]. However, patients with AIAIDs, PIDs, and SIDs were not enrolled in these phase 3 studies and therefore it is not possible to draw definitive conclusions for the safety and efficacy in these patients. 
Table 4. Characteristics of anti-COVID-19 vaccines available or in advanced phase of approval.

\begin{tabular}{|c|c|c|c|c|c|c|}
\hline Vaccines & Composition & Cellular Immunity & $\begin{array}{l}\text { Neutralizing } \\
\text { Antibodies }\end{array}$ & Doses & Efficacy & References \\
\hline $\begin{array}{c}\text { Pfizer } \\
\text { Comirnaty }\end{array}$ & $30 \mu \mathrm{g}$ mRNA Spike & Yes & Yes & $\begin{array}{c}2,3 \text { weeks } \\
\text { apart }\end{array}$ & $95 \%$ & [28] \\
\hline $\begin{array}{l}\text { Moderna } \\
\text { Spikevax }\end{array}$ & $\begin{array}{l}100 \mu \mathrm{g} \text { mRNA } \\
\text { Spike }\end{array}$ & Yes & Yes & $\begin{array}{l}2,4 \text { weeks } \\
\text { apart }\end{array}$ & $94.1 \%$ & [29] \\
\hline $\begin{array}{l}\text { AstraZeneca } \\
\text { Vaxzevria }\end{array}$ & $\begin{array}{l}\text { Non-replicating } \\
\text { viral vector Spike } \\
\text { DNA }\end{array}$ & Yes & Yes & $\begin{array}{l}2,4-12 \\
\text { weeks } \\
\text { apart }\end{array}$ & $70 \%$ & {$[21,22]$} \\
\hline Janssen (J\&J) & $\begin{array}{c}\text { Non-replicating } \\
\text { viral vector Spike } \\
\text { DNA }\end{array}$ & Yes & Yes & 1 & $\begin{array}{l}73-82 \% \text { at } \\
14-28 \text { days, } \\
\text { respectively }\end{array}$ & {$[23,24]$} \\
\hline $\begin{array}{c}\text { Cansino } \\
\text { Biological Inc. }\end{array}$ & $\begin{array}{c}\text { Non-replicating } \\
\text { viral vector Spike } \\
\text { DNA }\end{array}$ & & Yes & 1 & & [25] \\
\hline $\begin{array}{c}\text { Sinovac } \\
\text { CoronaVac }\end{array}$ & $\begin{array}{l}\text { Inactivated whole } \\
\text { virus }\end{array}$ & & Yes & $\begin{array}{l}2,2 \text { weeks } \\
\text { apart }\end{array}$ & $83.5 \%$ & {$[30,31]$} \\
\hline $\begin{array}{l}\text { Gamaleya } \\
\text { Res. Institute }\end{array}$ & $\begin{array}{l}\text { Non-replicating } \\
\text { viral vector Spike } \\
\text { DNA }\end{array}$ & & Yes & $\begin{array}{l}2,3 \text { weeks } \\
\text { apart }\end{array}$ & $91.6 \%$ & {$[26,27]$} \\
\hline $\begin{array}{c}\text { BBV152 } \\
\text { Bharat } \\
\text { Biotech }\end{array}$ & $\begin{array}{l}\text { Inactivated whole } \\
\text { virus }\end{array}$ & & Yes & $\begin{array}{l}\text { 2, } 2 \text { weeks } \\
\text { apart }\end{array}$ & & {$[32,33]$} \\
\hline Novavax & $\begin{array}{c}\text { Recombinant } \\
\text { Spike+ Adjuvant }\end{array}$ & Yes & Yes & $\begin{array}{l}2,3 \text { weeks } \\
\text { apart }\end{array}$ & $89.7 \%$ & {$[19,20]$} \\
\hline
\end{tabular}

A very rare, severe, unpredictable, and frequently lethal thrombosis in uncommon sites, such as the cerebral venous sinus and the splanchnic venous circulation, has emerged in post-approval vaccine safety surveillance after large-scale vaccination. It is characterized by thrombocytopenia and anti-PF4 IgG antibodies and has been associated with administration of non-replicating viral vector vaccines (AstraZeneca and Janssen/Johnson \& Johnson vaccines). Its pathology shares some characteristics with the heparin-induced thrombocytopenia [34] and has been named "vaccine-induced immune thrombotic thrombocytopenia" (VITT) [35]. Lethality is approximately $50 \%$ in Europe with AstraZeneca and approximately $25 \%$ in the USA with Janssen/Johnson \& Johnson [36], especially in women $<60$ years old. The alarm caused by the deaths of healthy young people, mainly women, induced the Italian Medicines Agency (AIFA) to recommend the AstraZeneca vaccine only for subjects $>60$ years old, considering the higher risk of VITT in younger people, who, however, have a lower risk of getting infected with a severe form of COVID-19. Moreover, the hesitancy of the population towards Vaxzevria pushed the health authorities in many countries to consider the possibility of a heterologous prime boost in people who had received the first dose of Vaxzevria, although the risk of getting VITT following the second dose is even substantially lower than the already low risk associated with the first dose. The heterologous prime-boost vaccine policy is successful with other vaccines [37], such as polio [38]. This seems to be the case even for COVID-19, as shown at experimental $[39,40]$ and clinical levels by the Spanish study CombiVacS, carried out on over 660 subjects already vaccinated with the first Vaxzevria dose, who received a second dose of a Pfizer mRNA vaccine not before eight weeks following the first dose [41]. This heterologous approach, in analogy with the observation in experimental animals [40], appears highly effective also in humans, with immune responses even higher than those observed after two mRNA vaccine doses. Recently, in 88 health care workers who had received a first dose of Vaxzevria, 37 chose a homologous and 51 a heterologous booster with mRNA-1273 (Moderna). Seven-ten days 
following the second dose, those who had received the homologous booster had a five-fold increase of specific anti-Spike and anti-receptor binding domain (RBD) of severe acute respiratory syndrome coronavirus 2 (SARS-CoV-2) antibodies compared with the pre-booster levels, whereas those who chose the heterologous booster had a 115-fold and 125-fold increase of anti-Spike and anti-RBD antibodies, respectively [42]. However, a preliminary study on 830 subjects, in whom the adverse effects (AEs) were analyzed following either two doses of the same vaccine, Pfizer or AstraZeneca, or two doses of different vaccine types, the first Pfizer and the second AstraZeneca, or vice versa, showed a higher prevalence of AEs in the group receiving different vaccine types than the group receiving the same type [43]. The higher prevalence of AEs in patients receiving heterologous vaccine doses was not confirmed in two smaller studies, the first on 326 healthcare workers [44] and the other on 26 subjects [45]. In the latter study, cellular and humoral immunogenicity were explored and the results confirmed the data on the high stimulation of the immune system by the heterologous immunization already observed in the Spanish study, even towards the variants of concern. This vaccine strategy has been adopted in Italy and in some other European countries. It may be adopted not only for the second vaccine dose, but even for the possible follow-up doses, which may become necessary in consequence of the emergence of new viral variants poorly addressed by the current vaccines and in the case of passage of the pandemic to an endemic state, similar to influenza.

Anti-COVID-19 vaccines based on the mRNA technology, such as those developed by Pfizer/Biontech (Comirnaty) [28] and Moderna (Spikevax) [29], have never been used before in large-scale vaccination programs. mRNA coding for the Spike protein of SARSCoV-2 is delivered in lipid nanoparticles to favor its entry into the cell and to protect it from circulating and tissue RNAses [46,47]. This new category of vaccines, composed of nucleic acids and liposomes, is administered without adjuvants or vectors, considering that mRNA behaves as an adjuvant by interacting with intracellular (endosomal) Toll-like receptors (TLRs), thus activating the inflammation networks [46]. Published data on the phase 3 trials of the two already authorized vaccines refer to a non-infected population of over 43,000 and 30,000 subjects, respectively, treated with two vaccine doses (each of 30 and $100 \mu \mathrm{g}$, respectively) or placebo. After four months of observation, the groups treated with the two vaccines showed an efficacy, which is a reduction of disease cases (effectiveness has the same meaning, but it is used in real-life conditions), of $95 \%$ and $94.1 \%$, respectively, compared to the group of subjects who had received placebo, and the safety was considered optimal (Table 4) $[28,29]$. These similar results are very important, + .2as they have been obtained on two different populations, immunized with different, but very similar, vaccines produced with the same technology. Although in the pre-approval studies details on the possible presence of patients with AIAIDs in the study population were not provided, recently a study reporting 325 patients with rheumatic diseases who had received the first dose of an mRNA vaccine (51\% Pfizer and $49 \%$ Moderna) was published. Observed AEs were no more frequent and/or serious than those reported in the general population and disease flare-ups were not described in vaccinated patients [48]. The same results were obtained in two recent smaller studies, including 26 and 70 patients, respectively [49,50]. The mRNA vaccines are generally well tolerated, with transient local and systemic AEs. In the first phase of large-scale immunization, mainly in the USA, the most serious AE was represented by the anaphylactic shock from sensitization to polyethylene-glycol 2000, which occurred rarely but was approximately 10 -fold more frequent than with traditional vaccines and often in non-allergic people [47]. Following Pfizer and Moderna vaccines, 20 cases of thrombocytopenia were recently described in the USA [51]. In 17 subjects, prevaccine thrombocytopenia was not present. Although the relationship with the vaccine has not been definitively demonstrated, in 19 cases thrombocytopenia appeared after the first vaccine dose. However, the severity was milder and the prognosis favorable compared to VITT. Recently, in Israel and the USA, a very rare $(1 / 100,000$ and $0.52 / 100,000$, respectively) post-mRNA vaccine myocarditis, mainly occurring in $<30$-year-old men after the second dose, has been described [52]. A retrospective study on 23 post-vaccine cases of myocarditis 
occurring in the US military suggests that the observed cases were higher than expected and that in 16/23 cases cardiac symptoms resolved within one week, whereas in the other seven cases, symptoms continued to the time of the publication of the study [30].

The inactivated traditional vaccine from Sinovac seems to be well tolerated and quite immunogenic [31], even in children and adolescents 3-17 years old, as observed in a phase $1 / 2$ study [32], and an efficacy of $83.5 \%$ was just reported [33]. Another inactivated vaccine with an adjuvant, BBV152, is approved in India [18]. Its safety and immunogenicity seem satisfactory, whereas poor information is available on adaptive cellular immunity [53] and efficacy, considering that a phase 3 study has not yet been published. The vaccineinduced protection appears complete in rhesus macaques [54].

Regarding the fear that the currently approved vaccines may fail to mitigate or prevent infection with the viral variants of concern, the analyses carried out on the sera of the vaccinated subjects indicate that the immune response may be unmodified or reduced, whereas for all these variants increased transmissibility [55-58] and disease severity [59-63] have been identified (Table 5) [64]. However, published data show a markedly reduced neutralizing capacity towards the South-African B.1.351 (now denominated beta) variant of $2 / 3$ for the Pfizer vaccine [65] and of $1 / 6$ for the Moderna vaccine [66]. A marked reduction has even been reported for the AstraZeneca vaccine [56]; for this reason, its trial in Africa was cancelled. It must be underlined that up to now a clear identification of the threshold for protection of neutralizing antibodies is lacking. Moreover, the adaptive cellular immunity may replace the lack of protective antibodies [67]. Thus, it is still premature to assert that the virus variants, in particular the South-African one, are not covered by the currently approved vaccines; moreover, not-yet-approved vaccines seem to be more active against the variants $[68,69]$. As a further confirmation, there is the recently published use of the Pfizer vaccine in Qatar, where 50\% of the COVID-19 cases are due to the South-African variant and $44.5 \%$ to the B.1.1.7. (so-called English, currently denominated alpha) variant; the vaccine-induced protection against infection by the English variant was $89.5 \%$ and by the South-African variant was $75 \%$ two weeks after the second dose, but $100 \%$ towards severe disease by the two variants [70]. The sera of subjects vaccinated with two doses of Comirnaty or Vaxzevria and collected between one and four weeks from the second dose showed a significant 2.6-fold and 2.9-fold reduction, respectively, of neutralizing activity against the P.1 Brazilian variant (currently denominated gamma) compared to the Victoria viral strain [71]. However, on the basis of epidemiological data showing a possible prevalent circulation of new variants of concern, which may be poorly recognized by the current vaccines (this seemed to be the case for B.1.617.2, the so-called Indian variant, currently denominated delta, even though preliminary data show an effectiveness of $79 \%$ for Comirnaty and $60 \%$ for Vaxzevria [69], which was recently reconfirmed as $88 \%$ and $67 \%$, respectively [72]), it is assumed that the administration of a further dose of vaccine will occur that is adequately modified to intercept the new prevalent variants. In fact, the currently approved vaccines are easily and quickly modifiable in order to be tailored to the prevalent variants (Pfizer-Biontech Press release, 8 July 2021). Considering that the RNA viruses have a marked trend to mutate, the possibility that the general population will be forced to be vaccinated every year towards the prevalent circulating variant, as with influenza, is a likely scenario. However, for the general population, similarly to influenza, annual boosters might be envisaged, and it is possible that additional doses should be considered for vulnerable immunosuppressed patients, mounting an inadequate protective immune response after a conventional cycle of vaccination, as observed in transplanted patients [73], probably in relation to the treatment with mycophenolate and glucocorticoids [74]. Indeed, in over 100 transplanted patients, 44\% reached a meaningful antibody production only following a third vaccine dose [75], and one patient with AIAD needed to receive four doses to develop seropositivity [76]. 
Table 5. SARS-CoV-2 variants of concern (from Ref. [64] modified).

\begin{tabular}{cccccc}
\hline WHO Label & Lineage & Country of Isolation & Transmissibility & Disease Severity & Vaccine Protection \\
\hline Alpha & B.1.1.7 & United Kingdom & Increased & Increased & Unmodified \\
\hline Beta & B.1.351 & South Africa & Increased & Increased & Reduced \\
\hline Gamma & P.1 & Brazil & Increased & Increased & Reduced \\
\hline Delta & B.1.617.2 & India & Increased & Increased & Reduced \\
\hline
\end{tabular}

Neutralizing antibodies against the original viral strain from Wuhan were always present in the sera from subjects who recovered from COVID-19, whereas they were identified only sporadically against the B.1.351 variant. However, following one booster with an mRNA vaccine, the neutralizing capacity, even towards the variants, increased one thousand-fold, whereas a second dose did not have further effect [77]. These data have been recently confirmed [78,79], thus providing a solid scientific basis for the recommendation of administering a single vaccine dose in subjects who have recovered from COVID-19 infection.

Considering that the vaccines are innovative and have been authorized and used for only a few months, nothing is known about the possible appearance of long-term AEs after vaccination and the duration of immune response at protective levels. In fact, registration studies have only been observed during a four-month period. However, it is known that humoral immunity towards SARS-CoV-1 disappears after two-three years, whereas adaptive cellular immunity persists for a longer time [80,81]. Recently, a study was published showing that post-infection anti-COVID-19 neutralizing antibodies persist at protective levels up to eight months [82], and probably even more [78].

A further relevant issue is the type of vaccine-induced protection, whether addressed to prevent infection or only disease severity. The vaccine-induced protection observed in experimental models and in humans in phase 3 studies has not provided evidence that the vaccine prevents the possibility of infection $[22,24,28,29,83-85]$. However, the recent identification of salivary IgA in subjects vaccinated with two doses of mRNA vaccines [86] is reassuring because, even though its protective role has not been explored, it allows us to rule out the fear of a poor IgA mucosal immune response [87].

Pregnancy is listed as a contraindication on the labels of the Pfizer and Moderna vaccines, which the Food and Drug Administration (FDA) approved for emergency use. However, a critical analysis of this point is ongoing. EMA seems inclined to remove the warning. A preliminary study does not show relevant safety concerns [88] and even immunogenicity seems adequate [89], with the appearance of vaccine-induced antibodies which pass through the placenta and into milk. In fact, breastfeeding is not contraindicated. Recent data show a good safety and immunogenicity profile. Two weeks following vaccination, secretory IgA is already present in the maternal milk and remains, together with IgG, for approximately six weeks [90]. The pivotal role of secretory IgA in the SARS-CoV-2 neutralization has been recently underlined [91].

The mRNA vaccines have been approved for individuals older than 16 years (Pfizer) and 18 years (Moderna). However, recently the EMA has even approved Comirnaty Pfizer for administration to adolescents in the age range of 12-16 years, based on a study showing an excellent immune response in this age range [92]. Spikevax Moderna has filed for emergency approval of its COVID-19 vaccine for teens and the EMA has recently recommended granting an extension of its use to ages $12-17$ years.

\section{Safety of COVID-19 Vaccines in Patients with AIAIDs, PIDs, and SIDs}

The issue of safety of the COVID-19 vaccines has been based on what is already known for traditional vaccines (Tables 1-3) [1-15]. In general, patients with AIAIDs, PIDs, and SIDs may safely receive inactivated or subunit vaccines, whereas the living vaccines should generally be avoided. Moreover, in patients with AIAIDs the issue of a possible 
flare-up of a stabilized disease because of vaccine stimulation should be considered. This underlines the compatibility of adjuvanted vaccines with patients with AIAIDs: in fact, adjuvants may be useful in immunocompromised patients, but the hyper-stimulation of a deranged immune system may run uncontrolled. The COVID-19 innovative mRNA vaccines behave like an adjuvant, and this should carefully be considered in some AIAIDs. It must be underlined that in the pre-approval studies the observation period was relatively short. Moreover, in the study population of the pre-approval studies, no patients with AIAIDs or PIDs were included. Only a small percentage of patients with SIDs were enrolled, and their clinical data has not been reported. Further studies, including a larger sample of these patients, treated with different immunosuppressive drugs, and analyzed during a longer period, are mandatory. Despite the current lack of definitive recommendations, some preliminary studies [48-50], supported by a recent larger multicenter study [93], confirm that mRNA vaccines seem to be well tolerated in patients with AIAIDs, without the induction of flare-ups or more frequent and serious AEs than in the general population. Recently, herpes zoster appearance was described in 6/491 (1.2\%) patients with IMIDs (Immune-Mediated Inflammatory Disorders) following an mRNA vaccine [94]. In the general population, mRNA vaccines also show a very low frequency of serious AEs, lower than those observed in vectored vaccines. In general, patients with AIAIDs do not have contraindications to the COVID-19 vaccination. This remains true also for selective pathologies, such as vasculitis and/or autoimmune cytopenias, even in cases of previous neutropenia, anemia, and / or lymphocytopenia (the limits of the lymphocytopenia here considered are light $<1500 / \mu \mathrm{L}>1000 / \mu \mathrm{L}$; moderate $<1000 / \mu \mathrm{L}>500 / \mu \mathrm{L}$; severe $<500 / \mu \mathrm{L}$ [95-97]). The only risk is inducing a reduced and partially protective immune response. Patients should be vaccinated when the disease is stable in remission, in analogy with the behavior adopted with the traditional vaccines. Following the alarm caused by the appearance of VITT in rare subjects who had received the first dose of a viral vector non-replicating vaccine, such as Vaxzevria from AstraZeneca and Janssen/Johnson \& Johnson, the experts have faced the issue of COVID-19 vaccine compatibility with primary or PIDs-associated thrombocytopenia, with primary or secondary anti-phospholipid syndrome, and with taking anti-coagulant therapy. Regarding thrombocytopenia, 20 cases were recently described in the USA following Pfizer and Moderna vaccines [51], only three of whom presented with pre-vaccine thrombocytopenia. Although the relationship to the vaccine has not been definitively demonstrated, in almost all cases $(19 / 20)$ thrombocytopenia appeared after the first vaccine dose. Regarding the viral vector non-replicating vaccines (AstraZeneca and Janssen/Johnson \& Johnson), the very rare, but unpredictable, VITT (with cerebral and/or splanchnic or diffuse thrombosis) is very severe with a bad prognosis [36], especially in women $<60$ years old. Like the post-Pfizer and Moderna vaccine thrombocytopenia, which is not associated with thrombosis and has a better prognosis, VITT generally appears in apparently healthy individuals without pre-vaccine thrombocytopenia. Thus, subjects with primary or PIDs-associated thrombocytopenia must be immunized against COVID-19; however, like the non-thrombocytopenic patients with AIAIDs, PIDs, and SIDs, they should only be vaccinated with mRNA vaccines, and should not receive viral vector non-replicating vaccines. The same recommendation is true for patients with primary or secondary anti-phospholipid syndrome, who must be immunized only during remission. In addition, both types of patients (the thrombocytopenic ones and those with anti-phospholipid syndrome) should be carefully monitored in the post-vaccine phase. Finally, patients under anti-coagulation therapy, such as heparin, should not discontinue the therapy if mRNA vaccine administration is planned. Even though there is no evidence that heparin may precipitate VITT, the similar pathogenesis of heparin-induced thrombocytopenia (e.g., appearance of anti-PF4 antibodies) makes it seem prudent to replace heparin-like with non- heparin-like anticoagulants if administration of a viral vector non-replicating vaccine is planned [34].

Even patients with PIDs and SIDs do not seem to have contraindications to COVID-19 vaccines. In fact, no higher frequency of AEs was observed in two preliminary studies, 
the first one on 11 immune deficient patients (10 PIDs and 1 SID) [98] and the other on 26 patients with inborn errors of immunity (26 PIDs) [99], where substantial safety of the mRNA Pfizer vaccine and satisfactory immunogenicity was observed, except for the four patients with $\mathrm{X}$-linked agammaglobulinemia, in whom an adaptive cellular response was observed. A recent study confirmed the lack of antibody response in patients with $\mathrm{X}$-linked agammaglobulinemia, compensated by the induction of an adaptive cellular response, whereas the response of patients with Common Variable Immunodeficiency was found to be unsatisfactory and non-protective at both cellular and humoral levels [100]. Safety and substantial immunogenicity were observed in patients with onco-hematological diseases [101,102] and in hemodialysis patients [103]. Despite the absence of comparative studies between mRNA and viral vector non-replicating vaccines, data from scientific studies and reports of regulatory authorities indicate better protection from mRNA vaccines. Regarding safety, viral vector non-replicating vaccines have shown a higher frequency of severe AEs, such as the highly lethal VITT. Moreover, preliminary studies [48-50] have shown that mRNA vaccines may be safely administered to patients with AIAIDs. Thus, based on the current state of knowledge, the Task Force considered that mRNA vaccines should be the only ones to be administered in patients with AIAIDs, PIDs, and SIDs, unless more convincing safety and efficacy data on the use of viral vector non-replicating vaccines becomes available.

\section{Immunosuppressive/Immunomodulating Therapy and COVID-19 Vaccines}

The vaccine is more effective the lower the immunosuppression; however, the risk of a flare-up of the underlying disease following interruption of an immunosuppressive drug is real, thus, in general, no modification of immunosuppressive therapy, prior to, during, or following vaccination, is advisable. However, based on what has been observed with traditional vaccines (Tables 1-3) [1-15], immunosuppressive drugs may negatively interfere with the immune response to vaccines. There is agreement between the European League against Rheumatism (EULAR) [104] and the American College of Rheumatology (ACR) [105] that treatment with corticosteroids (CCS) and anti-CD20 monoclonal antibodies, such as rituximab as an inducer of $B$ cell death, markedly reduce the antibody response. Treatment with CCS should, therefore, be reduced to the minimum level compatible with disease control, which, however, is different between ACR ( $<20 \mathrm{mg}$ /day of prednisoneequivalent) and EULAR ( $<10 \mathrm{mg} /$ day). Even anti-CD20 monoclonal antibodies (mAbs) must be administered far away from vaccination (if clinical conditions allow, vaccination should be administered four weeks before the next scheduled cycle of rituximab and this cycle should be delayed and administered two-four weeks following the second vaccine dose). Recently, the issue of delaying the second dose of mRNA vaccines has been discussed and implemented in many countries, including Italy. Such a delay may be as long as two-three weeks more than the period approved in the label, up to a total of six weeks. In this case, the specialist may be forced to anticipate vaccination by two weeks, thus starting vaccination eight, instead of four, weeks before the next scheduled cycle of rituximab. A simplified scheme about the time intervals between ongoing therapy with rituximab and anti-COVID-19 vaccination is provided in Figure 1.

For the other immunosuppressive drugs, the EULAR and ACR positions are quite divergent. In fact, EULAR does not consider further possible interruptions of the immunosuppressive treatment, whereas ACR recommends the possible suspension of methotrexate (MTX), abatacept, and Janus kinase inhibitors (JKI), provided that the clinical conditions allow. MTX should be interrupted for one week after each vaccine dose, and subcutaneous abatacept for one week before and after the first vaccine dose. For intravenous abatacept, the first vaccine dose should be administered, if possible, four weeks following the drug infusion and the next infusion should be delayed by one week, if clinical conditions allow. JKI should be interrupted for one week after each vaccine dose. The last update of the ACR guidance was even more restrictive by introducing discontinuation of mycophenolate for one week following each vaccine dose and of acetaminophen and non-steroidal anti- 
inflammatory drugs (NSAIDs) $24 \mathrm{~h}$ prior to vaccination [106]. However, the limits on the use of immunosuppressive drugs in the vaccination period have been based on very few studies on traditional vaccines, generally counterbalanced by a higher number of reports, which did not show any significant negative interference in the immune response to vaccines, thus providing an explanation of the divergent recommendations. Recently, some studies have been published on the immune response to two-dose anti-COVID-19 mRNA vaccines in patients with AIAIDs under immunosuppressive therapy [49,50,93,107-109]. Geisen et al. reported that the immune response was adequate in 26 patients with chronic inflammatory conditions under immunosuppressive therapy [49]; Simon et al. studied 84 patients with AIAIDs and $10 \%$ of the patients were unable to respond vs. $1 \%$ of the healthy controls; moreover, such a reduced response was ascribed to the disease itself and not to the immunosuppressive therapy [50]. Spiera et al. analyzed 83 patients with rheumatic diseases, 30 of whom were treated with rituximab, and did not observe any immune response in 20/30 patients under rituximab, and in only one patient under belimumab [107]. Ruddy et al. observed a generally good response in 404 patients with AIAIDs, but a reduced response in patients under mycophenolate, rituximab, and CCS [108]. Haberman et al., by studying 82 patients with AIAIDs, observed a reduced antibody response $(62.2 \%$ vs. over $90 \%$ ) and a reduced CD8+ cellular response in the 45 patients under MTX [109]. Finally, Furer et al., in the largest multicentric study carried out in Israel on 686 patients immunized with two doses of Comirnaty Pfizer vaccine, observed a severely reduced immune response in patients under rituximab and a moderately reduced immune response in patients on CCS, abatacept, and mycophenolate mofetil, whereas only a mild impairment of immune response was observed because of MTX [93]. Thus, (even with mRNA vaccines) analogous to what has been observed with traditional vaccines, patients with AIAIDs may present a reduced vaccine-induced immune response because of the disease itself as well as immunosuppressive therapy, with CCS and anti-CD20 mAbs nearly always implicated in the immunosuppressive effect. However, for anti-CD20 mAbs, the marked reduction of the antibody response is associated with substantial maintenance of the adaptive cellular immunity, as originally observed with the influenza vaccine [13] and recently confirmed with anti-COVID-19 vaccines [110], even towards some variants of concern, such as B.1.1.7 and B.1.351 [111]. All the authorized COVID-19 vaccines can stimulate specific cellular immunity (Table 4) Moreover, immunosuppressive treatment has even been associated in some studies, with a protective effect on the cytokine release syndrome [112] observed in some cases of SARS-CoV-2 infection. All these considerations may explain the different evaluations by the different Scientific Societies/Colleges, including EULAR [104], ACR [105,106], and the Korean College of Rheumatology [113], which has an intermediate position compared to the other two. All agree on the inhibitory effect of CCS and anti-CD20 mAbs [114], either isolated or in combination. It should be underlined that in patients with stabilized AIAIDs, the dosage of the immunosuppressive drugs is generally lower than the threshold considered high-level [4]. Therefore, in these patients, it is preferable to provide partial protection with vaccination rather than risk disease reactivation because of immunosuppressive therapy interruption. CCS should be reduced up to the lowest level still compatible with disease control, at any rate $<10 \mathrm{mg}$ /day of prednisone-equivalent, and the anti-CD20 mAbs should be appropriately spaced around the vaccinations according to the ACR recommendations. For MTX, abatacept, JKI, and mycophenolate, the decision should be made by the immune system specialist based on the severity of the clinical picture and the possible risk of the even temporary interruption of the immunosuppressive treatment. The Task Force position regarding vaccination and immunosuppressive therapy is summarized in Table 6 


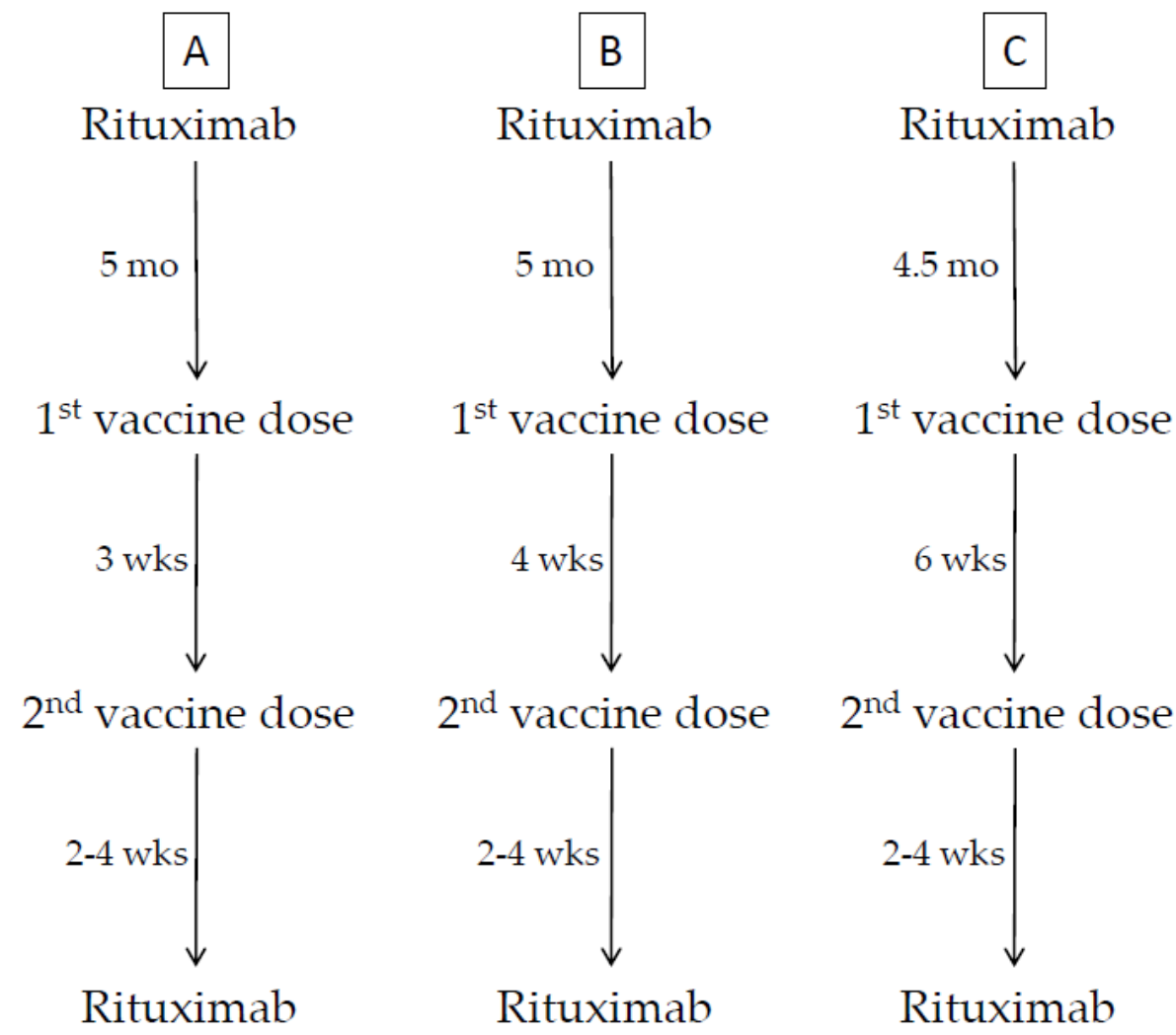

Total time 5-7 wks 6-8 wks

8-10 wks

Figure 1. Proposed protocol of time intervals between ongoing therapy with rituximab and anti-COVID-19 vaccination. The time intervals between two consequent treatments with rituximab and anti-COVID-19 vaccination are provided. Total time indicates the duration of the postponement of the next scheduled cycle of rituximab since the first vaccination. (A) Vaccination with BNT162 vaccine (Comirnaty, Pfizer) following the time interval between the two doses as approved in the label. (B) Vaccination with mRNA-1273 vaccine (Spikevax, Moderna) following the time interval between the two doses as approved in the label. (C) Vaccination with either BNT162 vaccine (Comirnaty, Pfizer) or mRNA-1273 vaccine (Spikevax, Moderna) with delay between the two doses, as implemented in Italy. Abbreviations: mo, months; wks, weeks.

Table 6. Guide to using anti-COVID-19 vaccination in patients with AIAIDs under immunosuppressive treatment [from Ref. [103] modified].

\begin{tabular}{|c|c|c|}
\hline Drug & Modification of Therapy & Modification of Therapy in Relation to Vaccination \\
\hline Hydroxychloroquine & $\mathrm{NO}$ & \\
\hline Apremilast & $\mathrm{NO}$ & \\
\hline IVIG & NO & \\
\hline $\begin{array}{l}\text { Glucocorticoids (Prednisone-equivalent }< \\
10 \mathrm{mg} / \text { day) }\end{array}$ & $\mathrm{NO}$ & \\
\hline $\begin{array}{l}\text { Glucocorticoids (Prednisone-equivalent } \\
\qquad 10 \mathrm{mg} / \text { day) }\end{array}$ & & $\begin{array}{c}\text { The dose should be reduced to }<10 \mathrm{mg} / \text { die, if possible, } \\
\text { before each vaccine dose }\end{array}$ \\
\hline Sulphasalazine & $\mathrm{NO}$ & \\
\hline Leflunomide & NO & \\
\hline Mycophenolate mofetil & & $\begin{array}{l}\text { Delay the dose, if }>20 \mathrm{mg} / \text { week, for } 1 \text { week for each } \\
\text { vaccine dose, in case of stable disease * }\end{array}$ \\
\hline
\end{tabular}


Table 6. Cont.

\begin{tabular}{|c|c|c|}
\hline Drug & Modification of Therapy & Modification of Therapy in Relation to Vaccination \\
\hline Azathioprine & $\mathrm{NO}$ & \\
\hline Cyclophosphamide (Oral) & $\mathrm{NO}$ & \\
\hline $\begin{array}{c}\mathrm{TNF} \alpha \text { inhibitors (Adalimumab, } \\
\text { Infliximab, Golimumab, Certolizumab, } \\
\text { Etanercept) }\end{array}$ & $\mathrm{NO}$ & \\
\hline Anti-IL-6R moAb (Tocilizumab) & $\mathrm{NO}$ & \\
\hline $\begin{array}{l}\text { IL-1 } \beta \text { inhibitors (Anakinra, } \\
\text { Canakinumab) }\end{array}$ & $\mathrm{NO}$ & \\
\hline $\begin{array}{l}\text { Anti-IL-17A moAbs (Secukinumab, } \\
\text { Ixekizumab) }\end{array}$ & $\mathrm{NO}$ & \\
\hline Anti-IL-12/23 moAb (Ustekinumab) & NO & \\
\hline $\begin{array}{l}\text { Anti-IL-23 moAbs (Tildrakizumab, } \\
\text { Guselkumab, Risankizumab) }\end{array}$ & $\mathrm{NO}$ & \\
\hline Anti-Blys moAb (Belimumab) & $\mathrm{NO}$ & \\
\hline Calcineurin inhibitors (oral) & $\mathrm{NO}$ & \\
\hline Methotrexate & & $\begin{array}{l}\text { Delay the dose, if }>20 \mathrm{mg} / \text { week, for } 1 \text { week for each } \\
\text { vaccine dose, in case of stable disease * }\end{array}$ \\
\hline JAK inhibitors & & Delay the dose for 1 week for each vaccine dose * \\
\hline Abatacept sc & & $\begin{array}{l}\text { Temporary interruption } 1 \text { week before and } 1 \text { week after } \\
\text { each vaccine dose * }\end{array}$ \\
\hline Abatacept iv & & $\begin{array}{l}\text { Each vaccine dose should be administered } 4 \text { weeks after } \\
\text { the last infusion and the next infusion should be } \\
\text { postponed } 1 \text { week }\end{array}$ \\
\hline Cyclophosphamide iv & & $\begin{array}{l}\text { The infusion should be administered } 1 \text { week after } \\
\text { vaccine * }\end{array}$ \\
\hline Anti-CD20 moAb (Rituximab) & & $\begin{array}{c}\text { The first vaccine dose should be administered } 4 \text { weeks } \\
\text { before the next scheduled cycle. Rituximab may be } \\
\text { administered not before } 3 \text { weeks after the second } \\
\text { vaccine dose, provided that the patient's clinical } \\
\text { condition allows. }\end{array}$ \\
\hline
\end{tabular}

* The risk-benefit evaluation of temporary immunosuppressive treatment interruption should be done by the immunology specialist based on the clinical picture. Regarding PIDs, the presence of Ig replacement therapy does not seem to have interfered with the cellular and humoral immune response observed in most patients, except for patients with X-linked agammaglobulinemia, who did not show antibody response, but were protected by the adaptive cellular immunity [98,99]. However, immunoglobulin for intravenous (IVIg) or subcutaneous (SCIg) use should not be administered in the same time period as vaccination, because it is impossible to check the humoral vaccine response, given that IVIg/SCIg may contain different concentrations of anti-SARS-CoV-2 antibodies [115,116]. Considering that the threshold level for protection is still unknown, it is generally recommended to avoid pre- and post-vaccine anti-SARS-CoV2 antibody testing. Nevertheless, post-vaccine antibody monitoring is indicated in vulnerable immunosuppressed patients [75,76], especially in patients with severe combined and humoral immune deficiency. In fact, in the case of lack of cellular and antibody response, in immunosuppressed patients the strategy of additional boosters may be tried, whereas in PIDs passive immunotherapy with mAbs or convalescent plasma may be considered should the anti-SARS-CoV-2 antibody levels in the IVIg/SCIg used for replacement therapy not be adequately represented.

Regarding SIDs, the rate of response by patients with solid tumors is optimal and higher than the one by patients with hematologic malignancies ( $98 \%$ vs. $85 \%$, respectively, especially in case of anti-CD20 therapy (70\%) and stem cell transplantation (73\%) [100], thus underlining once more the negative influence of some immunosuppressive treatments and the recommendation, when feasible, to vaccinate before immunosuppressive treatment is started. 


\section{Should Patients with AIAIDs, PIDs, and SIDs Be Prioritized in the Access to Vaccines?}

There is no general agreement regarding priority criteria for anti-COVID vaccine access for patients with AIAIDs, PIDs, and SIDs because there is no consensus on their actual risk of infection or developing a more serious disease. A large meta-analysis on over 300,000 patients with AIAIDs has shown that the risk of getting a COVID-19 infection is significantly higher than that of the general population, especially associated with previous steroid intake. However, COVID-19 prognosis does not seem to be any worse than that of the general population [117], even though single studies report a higher disease severity [118].

PIDs [119-122] do not show a higher risk of getting COVID-19 infection or of increased lethality compared to the general population, except for rare forms of congenital defects of interferon production, whereas conversely, SIDs, especially onco-hematological patients [102,123], are at higher risk of infection and lethality.

The best criterion, therefore, to evaluate the priority level of access to COVID-19 vaccine in these patients is the clinical one [124]: in patients with AIAIDs under heavy immunosuppressive therapy and a history of serious and recurrent infections, the immunology specialist will determine the priority level, in keeping with the Raccomandazioni ad interim sui gruppi target della vaccinazione anti-SARS-CoV-2/COVID-19 (GURI 24.3.2021), elaborated by the Italian Ministry of Health. It is necessary to emphasize that vulnerable patients with markedly dysfunctional immune systems may act as an incubator for SARS-CoV-2 variants. Because the established infection is not easily eliminated, it becomes chronic and the virus, under the pressure of the immune system, which is unable to clear it, mutates for survival [125]. This is a further consideration for prioritizing these patients in the access to vaccines to prevent the infection or, at least, a chronic infection. The Task Force does not consider it appropriate to interrupt/discontinue immunosuppressive therapy, excepting for high dosage CCS ( $\geq 10 \mathrm{mg}$ of prednisone-equivalent [104]) and antiCD20mAbs, such as rituximab [103-105] (Table 3). Moreover, in the case of MTX [105,106], abatacept [105,106], JKI [105,106], and mycophenolate [106], the immunology specialist should evaluate the possible discontinuation based on the clinical patients' characteristics.

Clinical criteria should guide the management of patients with PIDs and SIDs as well. For these patients, vaccination of cohabiting relatives and healthcare providers is recommended.

\section{Recommendations}

1. Anti-COVID-19 mass vaccination has personal and social benefits. Preventing the disease in single individuals may allow easier achievement of herd immunity, which is needed to interrupt the viral spread and protect individuals who cannot be vaccinated.

2. Vaccinations are a safe and effective tool for prevention and control of infectious diseases. Patients with AIAIDs, PIDs, and SIDs are at higher risk of infections, including those by SARS-COV-2. Few studies have addressed the issue of anti-COVID vaccination in these patients, but many are available on the safety, immunogenicity, efficacy, and possible contraindications of traditional vaccines in AIAIDs, PIDs, and SIDs patients. These studies may represent the basis on which to recommend the anti-COVID-19 vaccines [1-15] (Tables 1-3)

3. The vaccine is more effective the lower the immunosuppression; however, the risk of a flare-up of the underlying disease after the interruption of an immunosuppressive drug is real, thus, in general, no modification of immunosuppressive therapy either during or following vaccination is advisable. In particular cases, according to the clinical picture and the drugs used, modifications and/or discontinuations of immunosuppressive therapy may be recommended by the immunology specialist.

4. In general, inactivated vaccines or vaccines containing non-infectious viral sequences may be safely administered to patients with AIAIDs, PIDs, and SIDs in clinical remission [1-15] (Tables 1-3). Anti-COVID-19 vaccines of the traditional type that are 
composed by inactivated virus [31-33] or recombinant Spike protein and adjuvant [19], for which wider scientific knowledge and clinical experience are available, could preferentially be indicated in patients with AIAIDs, PIDs, and SIDs; however, no traditional vaccines are approved by the European Medicines Agency (EMA) yet (Table 4).

5. Viral vector non-replicating anti-COVID-19 vaccines, such as the ones from AstraZeneca (Vaxzevria) [21,22], Janssen/Johnson \& Johnson [23,24], Cansino Biological Inc. [25], and Gamaleya Research Institute [26,27] (Table 2), are known based on application to the anti-Ebola vaccine, however our knowledge of them is very limited. One problem with these vaccines is the previous and effective anti-viral vector immune response, which may totally inactivate the vaccine; however, this problem involves the general population, not only patients with AIAIDs, PIDs, and SIDs, and may be reduced by using viral vectors from primates. Although during the registration studies substantial safety of these vaccines has been observed [21], lack of patients with AIAIDs, PIDs, and SIDs in these studies does not allow definitive conclusions about the safety and efficacy of these vaccines in these patients. Moreover, recently the discovery of very rare, but severe and often lethal, cases of VITT prompted the regulatory agencies of many countries to substantially limit the use of these vaccines.

6. Anti-COVID-19 mRNA vaccines, such as those developed by Pfizer/Biontech [28] and Moderna [29], are brand new and the first ones to be used on a large scale. During the pre-approval studies, after four months of observation, the groups treated with the two vaccines showed an efficacy of $95 \%$ and $94.1 \%$, respectively, compared to the group of subjects who had received placebo, and the safety was considered optimal (Table 4) $[28,29]$. The mRNA vaccine effectiveness has also been calculated at $91 \%$ and $81 \%$ after the complete vaccine cycle or only the first dose, respectively [126]. Although in the pre-approval studies details on the possible presence of patients with AIAIDs in the study population have not been provided, recent studies have reported substantial safety and immunogenicity of these vaccines in patients with AIAIDs [48-50,92,106-108]. Even in PIDs, two preliminary studies [98,99] have shown the substantial safety and immunogenicity of the mRNA vaccines. Finally, COVID-19 vaccines were safe and immunogenic in onco-hematologic pathologies, and mRNA vaccines were more immunogenic than the adenoviral vaccine [101]. Despite the absence of currently released definitive recommendations, the cited preliminary studies confirm that mRNA vaccines seem to be well tolerated in patients with AIAIDs, PIDs, and SIDs. In the general population as well, mRNA vaccines show a very low frequency of serious adverse events, lower than those observed in vectored vaccines. The Task Force believes that, based on the data reported above, mRNA vaccines should be chosen for use in clinically stabilized patients with AIAIDs, PIDs, and SIDs.

7. There is no general agreement regarding priority criteria for anti-COVID vaccine access for patients with AIAIDs, PIDs, and SIDs, because there is no consensus on their actual risk of infection or developing a more serious disease. The best criterion to evaluate the priority level of access to COVID-19 vaccine in these patients is the clinical one [124]: in patients with AIAIDs under heavy immunosuppressive therapy and a history of serious and recurrent infections, the immunology specialist should determine the priority level, in keeping with the Raccomandazioni ad interim sui gruppi target della vaccinazione anti-SARS-CoV-2/COVID-19 (GURI 24.3.2021), elaborated by the Italian Ministry of Health. Clinical criteria should guide the management of patients with PIDs and SIDs as well. For these patients, vaccination of cohabiting relatives and healthcare providers is recommended.

8. The Task Force does not consider it appropriate to interrupt/discontinue immunosuppressive therapy, excepting for high dosage CCS ( $\geq 10 \mathrm{mg}$ of prednisone-equivalent [104]) and anti-CD20 mAbs, such as rituximab [103-105] (Table 6). Moreover, in the case of 
MTX [105,106], abatacept [105,106], JKI [105,106], and mycophenolate [106], the immunology specialist will evaluate the possible discontinuation based on the patients' clinical characteristics. Regarding PIDs, the risk of non-response should be evaluated, especially in severe combined and humoral immunodeficiencies. In the case of non-response passive immunotherapy with mAbs or convalescent plasma, vaccination should carefully be considered.

9. The patient's immunology specialist should be continuously updated and available for evaluating the vaccination risk level (disease activity and immunosuppression consequent to the current therapy) of the patient. The specialist should be continuously informed and able to provide all information useful for handling treatment during the vaccination period.

10. In keeping with the activity of the Italian Drug Agency (AIFA) to inform the whole population, the three Italian Immunological Societies will make available all data coming from studies carried out on immunized populations as soon as possible, using the sites or the traditional communication channels available to the members of scientific societies and the patient associations.

\section{Conclusions}

The COVID-19 pandemic has presented an unprecedented global challenge for humankind by causing deep and unimaginable consequences at the health, social, and economic levels. However, combined efforts in research have paved the way for an innovative new class of highly effective vaccines to be developed in less than one year. These vaccines, never used before, appear safe, effective, and easy to be tailored to new viral threats that may appear in the future. We believe that these new vaccines have a bright future and potentially represent powerful preventative weapons against dangerous pathological entities.

Funding: This research received no external funding.

Institutional Review Board Statement: Not applicable.

Informed Consent Statement: Not applicable.

Acknowledgments: Authors wish to thank Rita Carsetti (Bambino Gesù Children's Hospital, IRCCS, Rome), Francesco Liotta (Dept. of Clinical and Experimental Medicine, University of Florence, Florence), and Domenico Mavilio (Dept. of Medical Biotechnologies and Translational Medicine, Medical School of Milan University, Milan) for their contribution to updating the manuscript.

Conflicts of Interest: The authors declare no conflict of interest.

\section{References}

1. Salemi, S.; D’Amelio, R. Are Anti-Infectious Vaccinations Safe and Effective in Patients with Autoimmunity? Int. Rev. Immunol. 2010, 29, 270-314. [CrossRef] [PubMed]

2. Kochar, B.; Herfarth, H.H. Vaccinations in Adult Patients with Inflammatory Bowel Diseases in the West. Inflamm. Intest. Dis. 2018, 3, 11-15. [CrossRef]

3. Zrzavy, T.; Kollaritsch, H.; Rommer, P.S.; Boxberger, N.; Loebermann, M.; Wimmer, I.; Winkelmann, A.; Zettl, U.K. Vaccination in Multiple Sclerosis: Friend or Foe? Front. Immunol. 2019, 10, 1883. [CrossRef] [PubMed]

4. Furer, V.; Rondaan, C.; Heijstek, M.W.; Agmon-Levin, N.; Van Assen, S.; Bijl, M.; Breedveld, F.C.; D'Amelio, R.; Dougados, M.; Kapetanovic, M.C.; et al. 2019 update of EULAR recommendations for vaccination in adult patients with autoimmune inflammatory rheumatic diseases. Ann. Rheum. Dis. 2020, 79, 39-52. [CrossRef] [PubMed]

5. Rondaan, C.; Furer, V.; Heijstek, M.W.; Agmon-Levin, N.; Bijl, M.; Breedveld, F.C.; D'Amelio, R.; Dougados, M.; Kapetanovic, M.C.; Van Laar, J.M.; et al. Efficacy, immunogenicity and safety of vaccination in adult patients with autoimmune inflammatory rheumatic diseases: A systematic literature review for the 2019 update of EULAR recommendations. RMD Open 2019, 5 , e001035. [CrossRef]

6. Martire, B.; Azzari, C.; Badolato, R.; Canessa, C.; Cirillo, E.; Gallo, V.; Graziani, S.; Lorenzini, T.; Milito, C.; Panza, R.; et al. Vaccination in immunocompromised host: Recommendations of Italian Primary Immunodeficiency Network Centers (IPINET). Vaccine 2018, 36, 3541-3554. [CrossRef]

7. Eibl, M.M.; Wolf, H.M. Vaccination in patients with primary immune deficiency, secondary immune deficiency and autoimmunity with immune regulatory abnormalities. Immunotherapy 2015, 7, 1273-1292. [CrossRef] 
8. Rubin, L.G.; Levin, M.J.; Ljungman, P.; Davies, E.G.; Avery, R.K.; Tomblyn, M.; Bousvaros, A.; Dhanireddy, S.; Sung, L.; Keyserling, H.; et al. Executive Summary: 2013 IDSA Clinical Practice Guideline for Vaccination of the Immunocompromised Host. Clin. Infect. Dis. 2014, 58, 309-318. [CrossRef]

9. Bitterman, R.; Eliakim-Raz, N.; Vinograd, I.; Trestioreanu, A.Z.; Leibovici, L.; Paul, M. Influenza vaccines in immunosuppressed adults with cancer. Cochrane Database Syst. Rev. 2018, 2, CD008983. [CrossRef]

10. Germano, V.; Cattaruzza, M.S.; Osborn, J.; Tarantino, A.; Di Rosa, R.; Salemi, S.; D'Amelio, R. Infection risk in Rheumatoid Arthritis and Spondyloarthropathy patients under treatment with DMARDs, Corticosteroids and TNF- $\alpha$ antagonists. J. Transl. Med. 2014, 12, 77. [CrossRef]

11. Consiglio Superiore di Sanità. Guida Alle Controindicazioni Alle Vaccinazioni, 5th ed.; A Cura di Giovanni Gallo, Rosanna Mel, Elisa Ros e Antonietta Filia; Consiglio Superiore di Sanità: Rome, Italy, 2018.

12. Caporuscio, S.; Ieraci, R.; Valesini, G.; Teloni, R.; Mariotti, S.; Spinelli, F.R.; Ferlito, C.; Salemi, S.; Diamanti, A.P.; Meneguzzi, G.; et al. Anti-polysaccharide and anti-diphtheria protective antibodies after 13-valent pneumococcal conjugate vaccination in rheumatoid arthritis patients under immunosuppressive therapy. Clin. Immunol. 2018, 195, 18-27. [CrossRef] [PubMed]

13. Arad, U.; Tzadok, S.; Amir, S.; Mandelboim, M.; Mendelson, E.; Wigler, I.; Sarbagil-Maman, H.; Paran, D.; Caspi, D.; Elkayam, $\mathrm{O}$. The cellular immune response to influenza vaccination is preserved in rheumatoid arthritis patients treated with rituximab. Vaccine 2011, 29, 1643-1648. [CrossRef] [PubMed]

14. Croce, E.; Hatz, C.; Jonker, E.; Visser, L.; Jaeger, V.; Bühler, S. Safety of live vaccinations on immunosuppressive therapy in patients with immune-mediated inflammatory diseases, solid organ transplantation or after bone-marrow transplantation-A systematic review of randomized trials, observational studies and case reports. Vaccine 2017, 35, 1216-1226. [CrossRef] [PubMed]

15. Centers for Disease Control and Prevention; Infectious Disease Society of America; American Society of Blood and Marrow Transplantation. Guidelines for preventing opportunistic infections among hematopoietic stem cell transplant recipients. MMWR Recomm. Rep. 2000, 49, RR-10.

16. Hodgson, J. The pandemic pipeline. Nat. Biotechnol. 2020, 38, 523-532. [CrossRef] [PubMed]

17. Available online: https://www.who.int/publications/m/item/draft-landscape-of-covid-19-candidate-vaccines (accessed on 12 June 2021).

18. Lancet Commission on COVID-19 Vaccines and Therapeutics Task Force Members. Operation Warp Speed: Implications for global vaccine security. Lancet Glob. Health 2021, 9, e1017-e1021. [CrossRef]

19. Keech, C.; Albert, G.; Cho, I.; Robertson, A.; Reed, P.; Neal, S.; Plested, J.S.; Zhu, M.; Cloney-Clark, S.; Zhou, H.; et al. Phase 1-2 Trial of a SARS-CoV-2 Recombinant Spike Protein Nanoparticle Vaccine. N. Engl. J. Med. 2020, 383, 2320-2332. [CrossRef]

20. Heath, P.T.; Galiza, E.P.; Baxter, D.N.; Boffito, M.; Browne, D.; Burns, F.; Chadwick, D.R.; Clark, R.; Cosgrove, C.; Galloway, J.; et al. Safety and Efficacy of NVX-CoV2373 Covid-19 Vaccine. N. Engl. J. Med. 2021. [CrossRef]

21. Ramasamy, M.N.; Minassian, A.M.; Ewer, K.J.; Flaxman, A.L.; Folegatti, P.M.; Owens, D.R.; Voysey, M.; Aley, P.K.; Angus, B.; Babbage, G.; et al. Safety and immunogenicity of ChAdOx1 nCoV-19 vaccine administered in a prime-boost regimen in young and old adults (COV002): A single-blind, randomised, controlled, phase $2 / 3$ trial. Lancet 2021, 396, 1979-1993. [CrossRef]

22. Voysey, M.; Clemens, S.A.C.; Madhi, S.A.; Weckx, L.Y.; Folegatti, P.M.; Aley, P.K.; Angus, B.; Baillie, V.L.; Barnabas, S.L.; Bhorat, Q.E.; et al. Safety and efficacy of the ChAdOx1 nCoV-19 vaccine (AZD1222) against SARS-CoV-2: An interim analysis of four randomised controlled trials in Brazil, South Africa, and the UK. Lancet 2021, 397, 99-111. [CrossRef]

23. Stephenson, K.E.; Le Gars, M.; Sadoff, J.; de Groot, A.M.; Heerwegh, D.; Truyers, C.; Atyeo, C.; Loos, C.; Chandrashekar, A.; McMahan, K.; et al. Immunogenicity of the Ad26.COV2.S Vaccine for COVID-19. JAMA 2021, 325, 1535. [CrossRef]

24. Sadoff, J.; Gray, G.; Vandebosch, A.; Cárdenas, V.; Shukarev, G.; Grinsztejn, B.; Goepfert, P.A.; Truyers, C.; Fennema, H.; Spiessens, B.; et al. Safety and Efficacy of Single-Dose Ad26.COV2.S Vaccine against Covid-19. N. Engl. J. Med. 2021, 384, 2187-2201. [CrossRef] [PubMed]

25. Zhu, F.-C.; Li, Y.-H.; Guan, X.-H.; Hou, L.-H.; Wang, W.-J.; Li, J.-X.; Wu, S.-P.; Wang, B.-S.; Wang, Z.; Wang, L.; et al. Safety, tolerability, and immunogenicity of a recombinant adenovirus type-5 vectored COVID-19 vaccine: A dose-escalation, open-label, non-randomised, first-in-human trial. Lancet 2020, 395, 1845-1854. [CrossRef]

26. Logunov, D.Y.; Dolzhikova, I.V.; Zubkova, O.V.; Tukhvatullin, A.I.; Shcheblyakov, D.V.; Dzharullaeva, A.S.; Grousova, D.M.; Erokhova, A.S.; Kovyrshina, A.V.; Botikov, A.G.; et al. Safety and immunogenicity of an rAd26 and rAd5 vector-based heterologous prime-boost COVID-19 vaccine in two formulations: Two open, non-randomised phase $1 / 2$ studies from Russia. Lancet 2020, 396, 887-897. [CrossRef]

27. Logunov, D.Y.; Dolzhikova, I.V.; Shcheblyakov, D.V.; Tukhvatulin, A.I.; Zubkova, O.V.; Dzharullaeva, A.S.; Kovyrshina, A.V.; Lubenets, N.L.; Grousova, D.M.; Erokhova, A.S.; et al. Safety and efficacy of an rAd26 and rAd5 vector-based heterologous prime-boost COVID-19 vaccine: An interim analysis of a randomised controlled phase 3 trial in Russia. Lancet 2021, 397, 671-681. [CrossRef]

28. Polack, F.P.; Thomas, S.J.; Kitchin, N.; Absalon, J.; Gurtman, A.; Lockhart, S.; Perez, J.L.; Marc, G.P.; Moreira, E.D.; Zerbini, C.; et al. Safety and Efficacy of the BNT162b2 mRNA Covid-19 Vaccine. N. Engl. J. Med. 2020, 383, 2603-2615. [CrossRef] [PubMed]

29. Baden, L.R.; El Sahly, H.M.; Essink, B.; Kotloff, K.; Frey, S.; Novak, R.; Diemert, D.; Spector, S.A.; Rouphael, N.; Creech, C.B.; et al. Efficacy and Safety of the mRNA-1273 SARS-CoV-2 Vaccine. N. Engl. J. Med. 2021, 384, 403-416. [CrossRef] 
30. Montgomery, J.; Ryan, M.; Engler, R.; Hoffman, D.; McClenathan, B.; Collins, L.; Loran, D.; Hrncir, D.; Herring, K.; Platzer, M.; et al. Myocarditis Following Immunization with mRNA COVID-19 Vaccines in Members of the US Military. JAMA Cardiol. 2021. [CrossRef]

31. Zhang, Y.; Zeng, G.; Pan, H.; Li, C.; Hu, Y.; Chu, K.; Han, W.; Chen, Z.; Tang, R.; Yin, W.; et al. Safety, tolerability, and immunogenicity of an inactivated SARS-CoV-2 vaccine in healthy adults aged 18-59 years: A randomised, double-blind, placebo-controlled, phase $1 / 2$ clinical trial. Lancet Infect. Dis. 2021, 21, 181-192. [CrossRef]

32. Han, B.; Song, Y.; Li, C.; Yang, W.; Ma, Q.; Jiang, Z.; Li, M.; Lian, X.; Jiao, W.; Wang, L.; et al. Safety, tolerability, and immunogenicity of an inactivated SARS-CoV-2 vaccine (CoronaVac) in healthy children and adolescents: A double-blind, randomised, controlled, phase $1 / 2$ clinical trial. Lancet. Infect. Dis. 2021. [CrossRef]

33. Tanriover, M.D.; Doğanay, H.L.; Akova, M.; Güner, H.R.; Azap, A.; Akhan, S.; Köse, Ş.; Erdinç, F.Ş.; Akalın, E.H.; Tabak, Ö.F.; et al . Efficacy and safety of an inactivated whole-virion SARS-CoV-2 vaccine (CoronaVac): Interim results of a double-blind, randomised, placebo-controlled, phase 3 trial in Turkey. Lancet 2021, 398, 213-222. [CrossRef]

34. Scully, M.; Singh, D.; Lown, R.; Poles, A.; Solomon, T.; Levi, M.; Goldblatt, D.; Kotoucek, P.; Thomas, W.; Lester, W. Pathologic Antibodies to Platelet Factor 4 after ChAdOx1 nCoV-19 Vaccination. N. Engl. J. Med. 2021, 384, 2202-2211. [CrossRef]

35. Aleem, A.; Nadeem, A.J. Coronavirus (COVID-19) Vaccine-Induced Immune Thrombotic Thrombocytopenia (VITT) [Updated 18 July 2021]. In StatPearlas [Internet]; StatPearls Publishing: Treasure Island, FL, USA. Available online: https:/ /WWW.ncbi.nlm.nih. gov /books / NBK570605 (accessed on 18 July 2021).

36. See, I.; Su, J.R.; Lale, A.; Woo, E.J.; Guh, A.Y.; Shimabukuro, T.T.; Streiff, M.B.; Rao, A.K.; Wheeler, A.P.; Beavers, S.F.; et al. US Case Reports of Cerebral Venous Sinus Thrombosis with Thrombocytopenia After Ad26.COV2.S Vaccination, March 2 to April 21, 2021. JAMA 2021, 325, 2448. [CrossRef] [PubMed]

37. Kardani, K.; Bolhassani, A.; Shahbazi, S. Prime-boost vaccine strategy against viral infections: Mechanisms and benefits. Vaccine 2016, 34, 413-423. [CrossRef]

38. Ferlito, C.; Biselli, R.; Visco, V.; Cattaruzza, M.; Capobianchi, M.; Castilletti, C.; Lapa, D.; Nicoletti, L.; Marchi, A.; Magurano, F.; et al. Immunogenicity of Viral Vaccines in the Italian Military. Biomedicines 2021, 9, 87. [CrossRef] [PubMed]

39. He, Q.; Mao, Q.; An, C.; Zhang, J.; Gao, F.; Bian, L.; Li, C.; Liang, Z.; Xu, M.; Wang, J. Heterologous prime-boost: Breaking the protective immune response bottleneck of COVID-19 vaccine candidates. Emerg. Microbes Infect. 2021, 10, 629-637. [CrossRef]

40. Spencer, A.J.; McKay, P.F.; Belij-Rammerstorfer, S.; Ulaszewska, M.; Bissett, C.D.; Hu, K.; Samnuan, K.; Blakney, A.K.; Wright, D.; Sharpe, H.R.; et al. Heterologous vaccination regimens with self-amplifying RNA and adenoviral COVID vaccines induce robust immune responses in mice. Nat. Commun. 2021, 12, 2893. [CrossRef]

41. Callaway, E. Mix-and-match COVID vaccines trigger potent immune response. Nature 2021, 593, 491. [CrossRef] [PubMed]

42. Normark, J.; Vikström, L.; Gwon, Y.-D.; Persson, I.-L.; Edin, A.; Björsell, T.; Dernstedt, A.; Christ, W.; Tevell, S.; Evander, M.; et al. Heterologous ChAdOx1 nCoV-19 and mRNA-1273 Vaccination. N. Engl. J. Med. 2021. [CrossRef] [PubMed]

43. Shaw, R.H.; Stuart, A.; Greenland, M.; Liu, X.; Van-Tam, J.S.N.; Snape, M.D.; Com-COV Study Group. Heterologous prime-boost COVID-19 vaccination: Initial reactogenicity data. Lancet 2021, 397, 2043-2046. [CrossRef]

44. Hillus, D.; Schwarz, T.; Tober-Lau, P.; Vanshylla, K.; Hastor, H.; Thibeault, C.; Jentzsch, S.; Helbig, E.T.; Lippert, L.J.; Tscheak, P.; et al. Safety, reactogenicity, and immunogenicity of homologous and heterologous prime-boost immunisation with ChAdOx1 nCoV-19 and BNT162b2: A prospective cohort study. Lancet Respir. Med. 2021. [CrossRef]

45. Groß, R.; Zanoni, M.; Seidel, A.; Conzelmann, C.; Gilg, A.; Krnavek, D.; Erdemci-Evin, S.; Mayer, B.; Hoffmann, M.; Pöh-lmann, S.; et al. Heterologous ChAdOx1 nCoV-19 and BNT162b2 prime-boost vaccination elicits potent neutralizing anti-body responses and $\mathrm{T}$ cell reactivity. medRxiv 2021. [CrossRef]

46. Tregoning, J.S.; Brown, E.S.; Cheeseman, H.M.; Flight, K.E.; Higham, S.L.; Lemm, N.; Pierce, B.F.; Stirling, D.C.; Wang, Z.; Pollock, K.M. Vaccines for COVID-19. Clin. Exp. Immunol. 2020, 202, 162-192. [CrossRef]

47. Castells, M.C.; Phillips, E.J. Maintaining Safety with SARS-CoV-2 Vaccines. N. Engl. J. Med. 2021, 384, 643-649. [CrossRef]

48. Connolly, C.M.; Ruddy, J.A.; Boyarsky, B.J.; Avery, R.K.; Werbel, W.A.; Segev, D.L.; Garonzik-Wang, J.; Paik, J.J. Safety of the first dose of mRNA SARS-CoV-2 vaccines in patients with rheumatic and musculoskeletal diseases. Ann. Rheum. Dis. 2021, 80, 1100-1101. [CrossRef]

49. Geisen, U.M.; Berner, D.K.; Tran, F.; Sümbül, M.; Vullriede, L.; Ciripoi, M.; Reid, H.M.; Schaffarzyk, A.; Longardt, A.C.; Franzenburg, J.; et al. Immunogenicity and safety of anti-SARS-CoV-2 mRNA vaccines in patients with chronic inflammatory conditions and immunosuppressive therapy in a monocentric cohort. Ann. Rheum. Dis. 2021, annrheumdis-2021-220272. [CrossRef] [PubMed]

50. Simon, D.; Tascilar, K.; Fagni, F.; Krönke, G.; Kleyer, A.; Meder, C.; Atreya, R.; Leppkes, M.; Kremer, A.E.; Ramming, A.; et al. SARS-CoV-2 vaccination responses in untreated, conventionally treated and anticytokine-treated patients with immune-mediated inflammatory diseases. Ann. Rheum. Dis. 2021. [CrossRef] [PubMed]

51. Lee, E.J.; Cines, D.B.; Gernsheimer, T.; Kessler, C.; Michel, M.; Tarantino, M.D.; Semple, J.W.; Arnold, D.M.; Godeau, B.; Lambert, M.P.; et al. Thrombocytopenia following Pfizer and Moderna SARS-CoV-2 vaccination. Am. J. Hematol. 2021, 96, 534-537. [CrossRef]

52. Albert, E.; Aurigemma, G.; Saucedo, J.; Gerson, D.S. Myocarditis following COVID-19 vaccination. Radiol. Case Rep. 2021, 16, 2142-2145. [CrossRef] 
53. Ella, R.; Reddy, S.; Jogdand, H.; Sarangi, V.; Ganneru, B.; Prasad, S.; Das, D.; Raju, D.; Praturi, U.; Sapkal, G.; et al. Safety and immunogenicity of an inactivated SARS-CoV-2 vaccine, BBV152: Interim results from a double-blind, randomised, multicentre, phase 2 trial, and 3-month follow-up of a double-blind, randomised phase 1 trial. Lancet Infect. Dis. 2021, 21, 950-961. [CrossRef]

54. Yadav, P.D.; Ella, R.; Kumar, S.; Patil, D.R.; Mohandas, S.; Shete, A.M.; Vadrevu, K.M.; Bhati, G.; Sapkal, G.; Kaushal, H.; et al. Immunogenicity and protective efficacy of inactivated SARS-CoV-2 vaccine candidate, BBV152 in rhesus macaques. Nat. Commun. 2021, 12, 1386. [CrossRef] [PubMed]

55. Davies, N.G.; Abbott, S.; Barnard, R.C.; Jarvis, C.I.; Kucharski, A.J.; Munday, J.D.; Pearson, C.A.B.; Russell, T.W.; Tully, D.C.; Washburne, A.D.; et al. Estimated transmissibility and impact of SARS-CoV-2 lineage B.1.1.7 in England. Science 2021, 372, eabg3055. [CrossRef]

56. Madhi, S.A.; Baillie, V.; Cutland, C.L.; Voysey, M.; Koen, A.L.; Fairlie, L.; Padayachee, S.D.; Dheda, K.; Barnabas, S.L.; Bhorat, Q.E.; et al. Efficacy of the ChAdOx1 nCoV-19 Covid-19 Vaccine against the B.1.351 Variant. N. Engl. J. Med. 2021, 384, 1885-1898. [CrossRef]

57. Faria, N.R.; Mellan, T.A.; Whittaker, C.; Claro, I.M.; Candido, D.D.S.; Mishra, S.; Crispim, M.A.E.; Sales, F.C.S.; Hawryluk, I.; McCrone, J.T.; et al. Genomics and epidemiology of the P.1 SARS-CoV-2 lineage in Manaus, Brazil. Science 2021, 372, 815-821. [CrossRef]

58. Available online: https://assets.publishing.service.gov.uk/government/uploads/system/uploads/attachment_data/file/98 8619/Variants_of_Concern_VOC_Technical_Briefing_12_England.pdf (accessed on 3 July 2021).

59. Collier, D.A.; De Marco, A.; Ferreira, I.A.T.M.; Meng, B.; Datir, R.P.; Walls, A.C.; Kemp, S.A.; Bassi, J.; Pinto, D.; Fregni, C.S.; et al. Sensitivity of SARS-CoV-2 B.1.1.7 to mRNA vaccine-elicited antibodies. Nature 2021, 593, 136-141. [CrossRef] [PubMed]

60. Davies, N.G.; Jarvis, C.I.; CMMID COVID-19 Working Group; Edmunds, W.J.; Jewell, N.P.; Diaz-Ordaz, K.; Keogh, R.H. Increased mortality in community-tested cases of SARS-CoV-2 lineage B.1.1.7. Nature 2021, 593, 270-274. [CrossRef] [PubMed]

61. Available online: https://cmmid.github.io/topics/covid19/reports/sa-novel-variant/2021_01_11_Transmissibil-ity_and_ severity_of_501Y_V2_in_SA.pdf (accessed on 3 July 2021).

62. Available online: https://assets.publishing.service.gov.uk/government/uploads/system/uploads/attachment_data/file/97 5742/Variants_of_Concern_VOC_Technical_Briefing_8_England.pdf (accessed on 3 July 2021).

63. Sheikh, A.; McMenamin, J.; Taylor, B.; Robertson, C.; Public Health Scotland and the EAVE II Collaborators. SARS-CoV-2 Delta VOC in Scotland: Demographics, risk of hospital admission, and vaccine effectiveness. Lancet 2021, 397, 2461-2462. [CrossRef]

64. ECDC-European Center for Disease Control. SARS-CoV-2 Variants of Concern as of 6 May 2021. Available online: https: / / www.ecdc.europa.eu/en/covid-19/variants-concern (accessed on 3 July 2021).

65. Liu, Y.; Liu, J.; Xia, H.; Zhang, X.; Fontes-Garfias, C.R.; Swanson, K.A.; Cai, H.; Sarkar, R.; Chen, W.; Cutler, M.; et al. Neutralizing Activity of BNT162b2-Elicited Serum. N. Engl. J. Med. 2021, 384, 1466-1468. [CrossRef] [PubMed]

66. Wu, K.; Werner, A.P.; Koch, M.; Choi, A.; Narayanan, E.; Stewart-Jones, G.B.; Colpitts, T.; Bennett, H.; Boyoglu-Barnum, S.; Shi, W.; et al. Serum Neutralizing Activity Elicited by mRNA-1273 Vaccine. N. Engl. J. Med. 2021, 384, 1468-1470. [CrossRef] [PubMed]

67. Woldemeskel, B.A.; Garliss, C.C.; Blankson, J.N. SARS-CoV-2 mRNA vaccines induce broad CD4+ T cell responses that recognize SARS-CoV-2 variants and HCoV-NL63. J. Clin. Investig. 2021, 131, 2149335. [CrossRef] [PubMed]

68. Rubin, R. COVID-19 Vaccines vs Variants—Determining How Much Immunity Is Enough. JAMA 2021, 325, 1241. [CrossRef]

69. Shinde, V.; Bhikha, S.; Hoosain, Z.; Archary, M.; Bhorat, Q.; Fairlie, L.; Lalloo, U.; Masilela, M.S.; Moodley, D.; Hanley, S.; et al. Efficacy of NVX-CoV2373 Covid-19 Vaccine against the B.1.351 Variant. N. Engl. J. Med. 2021, 384, 1899-1909. [CrossRef] [PubMed]

70. Abu-Raddad, L.J.; Chemaitelly, H.; Butt, A.A.; National Study Group for COVID-19 Vaccination. Effectiveness of the BNT162b2 Covid-19 Vaccine against the B.1.1.7 and B.1.351 Variants. N. Engl. J. Med. 2021, 385, 187-189. [CrossRef]

71. Dejnirattisai, W.; Zhou, D.; Supasa, P.; Liu, C.; Mentzer, A.J.; Ginn, H.M.; Zhao, Y.; Duyvesteyn, H.M.; Tuekprakhon, A.; Nutalai, R.; et al. Antibody evasion by the P.1 strain of SARS-CoV-2. Cell 2021, 184, 2939-2954.e9. [CrossRef]

72. Bernal, J.L.; Andrews, N.; Gower, C.; Gallagher, E.; Simmons, R.; Thelwall, S.; Stowe, J.; Tessier, E.; Groves, N.; Dabrera, G.; et al. Effectiveness of Covid-19 Vaccines against the B.1.617.2 (Delta) Variant. N. Engl. J. Med. 2021, 385, 585-594. [CrossRef]

73. Boyarsky, B.J.; Werbel, W.A.; Avery, R.K.; Tobian, A.A.R.; Massie, A.B.; Segev, D.L.; Garonzik-Wang, J.M. Antibody Response to 2-Dose SARS-CoV-2 mRNA Vaccine Series in Solid Organ Transplant Recipients. JAMA 2021, 325, 2204-2206. [CrossRef] [PubMed]

74. Sattler, A.; Schrezenmeier, E.; Weber, U.A.; Potekhin, A.; Bachmann, F.; Straub-Hohenbleicher, H.; Budde, K.; Storz, E.; Proß, V.; Bergmann, Y.; et al. Impaired humoral and cellular immunity after SARS-CoV-2 BNT162b2 (tozinameran) prime-boost vaccination in kidney transplant recipients. J. Clin. Investig. 2021, 131, e150175. [CrossRef]

75. Kamar, N.; Abravanel, F.; Marion, O.; Couat, C.; Izopet, J.; Del Bello, A. Three Doses of an mRNA Covid-19 Vaccine in Solid-Organ Transplant Recipients. N. Engl. J. Med. 2021, 385, 661-662. [CrossRef]

76. Albach, F.N.; Burmester, G.R.; Biesen, R. Successful BNT162b2 booster vaccinations in a patient with rheumatoid arthritis and initially negative antibody response. Ann. Rheum. Dis. 2021. [CrossRef]

77. Stamatatos, L.; Czartoski, J.; Wan, Y.H.; Homad, L.J.; Rubin, V.; Glantz, H.; Neradilek, M.; Seydoux, E.; Jennewein, M.F.; MacCamy, A.J.; et al. mRNA vaccination boosts cross-variant neutralizing antibodies elicited by SARS-CoV-2 infection. Science 2021, 25, eabg9175. [CrossRef] 
78. Wang, Z.; Muecksch, F.; Schaefer-Babajew, D.; Finkin, S.; Viant, C.; Gaebler, C.; Hoffmann, H.H.; Barnes, C.O.; Cipolla, M.; Ramos, V.; et al. Naturally enhanced neutralizing breadth against SARS-CoV-2 one year after infection. Nature 2021, 595, 426-431. [CrossRef]

79. Mazzoni, A.; Di Lauria, N.; Maggi, L.; Salvati, L.; Vanni, A.; Capone, M.; Lamacchia, G.; Mantengoli, E.; Spinicci, M.; Zammarchi, L.; et al. First-dose mRNA vaccination is sufficient to reactivate immunological memory to SARS-CoV-2 in subjects who have recovered from COVID-19. J. Clin. Investig. 2021, 131, e149150. [CrossRef] [PubMed]

80. Yang, L.; Peng, H.; Zhu, Z.; Li, G.; Huang, Z.; Zhao, Z.; Koup, R.A.; Bailer, R.T.; Wu, C. Persistent memory CD4+ and CD8+ T-cell responses in recovered severe acute respiratory syndrome (SARS) patients to SARS coronavirus M antigen. J. Gen. Virol. 2007, 88 Pt 10, 2740-2748. [CrossRef]

81. Ng, O.-W.; Chia, A.; Tan, A.T.; Jadi, R.S.; Leong, H.N.; Bertoletti, A.; Tan, Y.-J. Memory T cell responses targeting the SARS coronavirus persist up to 11 years post-infection. Vaccine 2016, 34, 2008-2014. [CrossRef]

82. Dispinseri, S.; Secchi, M.; Pirillo, M.F.; Tolazzi, M.; Borghi, M.; Brigatti, C.; De Angelis, M.L.; Baratella, M.; Bazzigaluppi, E.; Venturi, G.; et al. Neutralizing antibody responses to SARS-CoV-2 in symptomatic COVID-19 is persistent and critical for survival. Nat. Commun. 2021, 12, 2670. [CrossRef]

83. Corbett, K.S.; Flynn, B.; Foulds, K.E.; Francica, J.R.; Boyoglu-Barnum, S.; Werner, A.P.; Flach, B.; O'Connell, S.; Bock, K.W.; Minai, M.; et al. Evaluation of the mRNA-1273 Vaccine against SARS-CoV-2 in Nonhuman Primates. N. Engl. J. Med. 2020, 383, 1544-1555. [CrossRef] [PubMed]

84. Van Doremalen, N.; Lambe, T.; Spencer, A.; Belij-Rammerstorfer, S.; Purushotham, J.N.; Port, J.R.; Avanzato, V.A.; Bushmaker, T.; Flaxman, A.; Ulaszewska, M.; et al. ChAdOx1 nCoV-19 vaccine prevents SARS-CoV-2 pneumonia in rhesus macaques. Nature 2020, 586, 578-582. [CrossRef]

85. Guebre-Xabier, M.; Patel, N.; Tian, J.-H.; Zhou, B.; Maciejewski, S.; Lam, K.; Portnoff, A.D.; Massare, M.J.; Frieman, M.B.; Piedra, P.A.; et al. NVX-CoV2373 vaccine protects cynomolgus macaque upper and lower airways against SARS-CoV-2 challenge. Vaccine 2020, 38, 7892-7896. [CrossRef] [PubMed]

86. Ketas, T.J.; Chaturbhuj, D.; Portillo, V.M.C.; Francomano, E.; Golden, E.; Chandrasekhar, S.; Debnath, G.; Diaz-Tapia, R.; Yasmeen, A.; Kramer, K.D.; et al. Antibody Responses to SARS-CoV-2 mRNA Vaccines Are Detectable in Saliva. Pathog. Immun. 2021, 6, 116-134. [CrossRef] [PubMed]

87. Prévost, J.; Gasser, R.; Beaudoin-Bussières, G.; Richard, J.; Duerr, R.; Laumaea, A.; Anand, S.P.; Goyette, G.; Benlarbi, M.; Ding, S.; et al. Cross-Sectional Evaluation of Humoral Responses against SARS-CoV-2 Spike. Cell Rep. Med. 2020, 1, 100126. [CrossRef]

88. Shimabukuro, T.T.; Kim, S.Y.; Myers, T.R.; Moro, P.L.; Oduyebo, T.; Panagiotakopoulos, L.; Marquez, P.L.; Olson, C.K.; Liu, R.; Chang, K.T.; et al. Preliminary Findings of mRNA Covid-19 Vaccine Safety in Pregnant Persons. N. Engl. J. Med. 2021, 384, 2273-2282. [CrossRef] [PubMed]

89. Collier, A.-R.Y.; McMahan, K.; Yu, J.; Tostanoski, L.H.; Aguayo, R.; Ansel, J.; Chandrashekar, A.; Patel, S.; Bondzie, E.A.; Sellers, D.; et al. Immunogenicity of COVID-19 mRNA Vaccines in Pregnant and Lactating Women. JAMA 2021, 325, 2370-2380. [CrossRef]

90. Perl, S.H.; Uzan-Yulzari, A.; Klainer, H.; Asiskovich, L.; Youngster, M.; Rinott, E.; Youngster, I. SARS-CoV-2-Specific Antibodies in Breast Milk After COVID-19 Vaccination of Breastfeeding Women. JAMA 2021, 325, 2013-2014. [CrossRef]

91. Wang, Z.; Lorenzi, J.C.C.; Muecksch, F.; Finkin, S.; Viant, C.; Gaebler, C.; Cipolla, M.; Hoffmann, H.-H.; Oliveira, T.Y.; Oren, D.A.; et al. Enhanced SARS-CoV-2 neutralization by dimeric IgA. Sci. Transl. Med. 2020, 13, eabf1555. [CrossRef]

92. Frenck, R.W.; Klein, N.P.; Kitchin, N.; Gurtman, A.; Absalon, J.; Lockhart, S.; Perez, J.L.; Walter, E.B.; Senders, S.; Bailey, R.; et al. Safety, Immunogenicity, and Efficacy of the BNT162b2 Covid-19 Vaccine in Adolescents. N. Engl. J. Med. 2021, 385, 239-250. [CrossRef]

93. Furer, V.; Eviatar, T.; Zisman, D.; Peleg, H.; Paran, D.; Levartovsky, D.; Zisapel, M.; Elalouf, O.; Kaufman, I.; Meidan, R.; et al. Immunogenicity and safety of the BNT162b2 mRNA COVID-19 vaccine in adult patients with autoimmune inflammatory rheumatic diseases and in the general population: A multicentre study. Ann. Rheum. Dis. 2021. [CrossRef]

94. Furer, V.; Zisman, D.; Kibari, A.; Rimar, D.; Paran, Y.; Elkayam, O. Herpes zoster following BNT162b2 mRNA COVID-19 vaccination in patients with autoimmune inflammatory rheumatic diseases: A case series. Rheumatology 2021, keab345. [CrossRef]

95. Warny, M.; Helby, J.; Nordestgaard, B.G.; Birgens, H.; Bojesen, S.E. Lymphopenia and risk of infection and infection-related death in 98,344 individuals from a prospective Danish population-based study. PLoS Med. 2018, 15, e1002685. [CrossRef]

96. Martin, M.; Guffroy, A.; Argemi, X.; Martin, T. Lupus érythémateux systémique et lymphopénie: Aspects cliniques et physiopathologiques. [Systemic lupus erythematosus and lymphopenia: Clinical and pathophysiological features]. Rev. Med. Interne 2017, 38, 603-613. [CrossRef]

97. Carli, L.; Tani, C.; Vagnani, S.; Signorini, V.; Mosca, M. Leukopenia, lymphopenia, and neutropenia in systemic lupus erythematosus: Prevalence and clinical impact-A systematic literature review. Semin. Arthritis Rheum. 2015, 45, 190-194. [CrossRef] [PubMed]

98. Squire, J.; Joshi, A. Seroconversion Following COVID-19 Vaccination in Immune Deficient Patients. Ann. Allergy Asthma Immunol. 2021. [CrossRef]

99. Hagin, D.; Freund, T.; Navon, M.; Halperin, T.; Adir, D.; Marom, R.; Levi, I.; Benor, S.; Alcalay, Y.; Freund, N.T. Immunogenicity of Pfizer-BioNTech COVID-19 vaccine in patients with inborn errors of immunity. J. Allergy Clin. Immunol. 2021. [CrossRef] 
100. Fernandez Salinas, A.; Piano Mortari, E.; Terreri, S.; Quintarelli, C.; Pulvirenti, F.; Di Cecca, S.; Guercio, M.; Milito, C.; Bonanni, L.; Auria, S.; et al. SARS-CoV-2 Vaccine Induced Atypical Immune Responses in Antibody Defects: Everybody does their best. medRxiv 2021. [CrossRef]

101. Thakkar, A.; Gonzalez-Lugo, J.D.; Goradia, N.; Gali, R.; Shapiro, L.C.; Pradhan, K.; Rahman, S.; Kim, S.Y.; Ko, B.; Sica, R.A.; et al. Seroconversion rates following COVID-19 vaccination among patients with cancer. Cancer Cell 2021, 39, 1081-1090.e2. [CrossRef]

102. Monin, L.; Laing, A.G.; Muñoz-Ruiz, M.; McKenzie, D.R.; Barrio, I.D.M.D.; Alaguthurai, T.; Domingo-Vila, C.; Hayday, T.S.; Graham, C.; Seow, J.; et al. Safety and immunogenicity of one versus two doses of the COVID-19 vaccine BNT162b2 for patients with cancer: Interim analysis of a prospective observational study. Lancet Oncol. 2021, 22, 765-778. [CrossRef]

103. Zitt, E.; Davidovic, T.; Schimpf, J.; Abbassi-Nik, A.; Mutschlechner, B.; Ulmer, H.; Benda, M.A.; Sprenger-Mähr, H.; Winder, T.; Lhotta, K. The Safety and Immunogenicity of the mRNA-BNT162b2 SARS-CoV-2 Vaccine in Hemodialysis Patients. Front. Immunol. 2021, 12, 704773. [CrossRef]

104. Bijlsma, J.W. EULAR December 2020 viewpoints on SARS-CoV-2 vaccination in patients with RMDs. Ann. Rheum. Dis. 2021, 80, 411-412. [CrossRef] [PubMed]

105. American College of Rheumatology. COVID-19 Vaccine Clinical Guidance Summary for Patients with Rheumatic and Musculoskeletal Diseases. Developed by the ACR COVID-19 Vaccine Clinical Guidance Task Force. This draft summary was ap-proved by the ACR Board of Directors on February 8, 2021, and updated on March 4, 2021. A full manuscript is pending journal peer review. Arthritis Rheumatol. 2021, 73, 1093-1107.

106. Curtis, J.R.; Johnson, S.R.; Anthony, D.D.; Arasaratnam, R.J.; Baden, L.R.; Bass, A.R.; Calabrese, C.; Gravallese, E.M.; Harpaz, R.; Kroger, A.; et al. American College of Rheumatology Guidance for COVID-19 Vaccination in Patients With Rheumatic and Musculoskeletal Diseases: Version 2. Arthritis Rheumatol. 2021, 73. [CrossRef]

107. Spiera, R.; Jinich, S.; Jannat-Khah, D. Rituximab, but not other antirheumatic therapies, is associated with impaired serological response to SARS- CoV-2 vaccination in patients with rheumatic diseases. Ann. Rheum. Dis. 2021. [CrossRef]

108. Ruddy, J.A.; Connolly, C.M.; Boyarsky, B.J.; Werbel, W.A.; Christopher-Stine, L.; Garonzik-Wang, J.; Segev, D.L.; Paik, J.J. High antibody response to two-dose SARS-CoV-2 messenger RNA vaccination in patients with rheumatic and musculoskeletal diseases. Ann. Rheum. Dis. 2021. [CrossRef]

109. Haberman, R.H.; Herati, R.; Simon, D.; Samanovic, M.; Blank, R.B.; Tuen, M.; Koralov, S.B.; Atreya, R.; Tascilar, K.; Allen, J.R.; et al. Methotrexate hampers immunogenicity to BNT162b2 mRNA COVID-19 vaccine in immune-mediated inflammatory disease. Ann. Rheum. Dis. 2021. [CrossRef]

110. Bonelli, M.M.; Mrak, D.; Perkmann, T.; Haslacher, H.; Aletaha, D. SARS-CoV-2 vaccination in rituximab-treated patients: Evidence for impaired humoral but inducible cellular immune response. Ann. Rheum. Dis. 2021. [CrossRef]

111. Westhoff, T.H.; Seibert, F.S.; Anft, M.; Blazquez-Navarro, A.; Skrzypczyk, S.; Doevelaar, A.; Hölzer, B.; Paniskaki, K.; Dolff, S.; Wilde, B.; et al. Correspondence on 'SARS-CoV-2 vaccination in rituximab-treated patients: Evidence for impaired humoral but inducible cellular immune response'. Ann. Rheum. Dis. 2021. [CrossRef] [PubMed]

112. Sarzi-Puttini, P.; Giorgi, V.; Sirotti, S.; Marotto, D.; Ardizzone, S.; Rizzardini, G.; Antinori, S.; Galli, M. COVID-19, cytokines and immunosuppression: What can we learn from severe acute respiratory syndrome? Clin. Exp. Rheumatol. 2020, 38, 337-342.

113. Park, J.K.; Lee, E.B.; Shin, K.; Sung, Y.-K.; Kim, T.H.; Kwon, S.-R.; Lee, M.S.; Hong, S.-J.; Choi, B.Y.; Lee, S.-S.; et al. COVID-19 Vaccination in Patients with Autoimmune Inflammatory Rheumatic Diseases: Clinical Guidance of the Korean College of Rheumatology. J. Korean Med. Sci. 2021, 36, e95. [CrossRef]

114. Deepak, P.; Kim, W.; Paley, M.A.; Yang, M.; Carvidi, A.B.; El-Qunni, A.A.; Haile, A.; Huang, K.; Kinnett, B.; Liebeskind, M.J.; et al. Glucocorticoids and B Cell Depleting Agents Substantially Impair Immunogenicity of mRNA Vaccines to SARS-CoV-2. medRxiv 2021. [CrossRef]

115. Díez, J.-M.; Romero, C.; Gajardo, R. Currently available intravenous immunoglobulin contains antibodies reacting against severe acute respiratory syndrome coronavirus 2 antigens. Immunotherapy 2020, 12, 571-576. [CrossRef] [PubMed]

116. Pisani, G.; Cristiano, K.; Simeoni, M.; Martina, A.; Pati, I.; Carocci, A.; Gaggioli, A.; Marino, F.; Adriani, D.; Pupella, S.; et al. Detection of antibodies against SARS-CoV-2 both in plasma pools for fractionation and in commercial intravenous immunoglobulins produced from plasma collected in Italy during the pandemic. Blood Transfus. 2021. [CrossRef]

117. Akiyama, S.; Hamdeh, S.; Micic, D.; Sakuraba, A. Prevalence and clinical outcomes of COVID-19 in patients with autoimmune diseases: A systematic review and meta-analysis. Ann. Rheum. Dis. 2020, 80, 384-391. [CrossRef] [PubMed]

118. Druyan, A.; Lidar, M.; Brodavka, M.; Levy, I.; Barzilai, A.; Pavlotsky, F. The risk for severe COVID 19 in patients with autoimmune and/or inflammatory diseases: First wave lessons. Dermatol. Ther. 2021, 34, e14627. [CrossRef]

119. Quinti, I.; Mezzaroma, I.; Milito, C. Clinical management of patients with primary immunodeficiencies during the COVID-19 pandemic. Expert Rev. Clin. Immunol. 2021, 17, 163-168. [CrossRef]

120. Quinti, I.; Lougaris, V.; Milito, C.; Cinetto, F.; Pecoraro, A.; Mezzaroma, I.; Mastroianni, C.M.; Turriziani, O.; Bondioni, M.P.; Filippini, M.; et al. A possible role for B cells in COVID-19? Lesson from patients with agammaglobulinemia. J. Allergy Clin. Immunol. 2020, 146, 211-213.e4. [CrossRef] [PubMed]

121. Meyts, I.; Bucciol, G.; Quinti, I.; Neven, B.; Fischer, A.; Seoane, E.; Lopez-Granados, E.; Gianelli, C.; Robles-Marhuenda, A.; Jeandel, P.-Y.; et al. Coronavirus disease 2019 in patients with inborn errors of immunity: An international study. J. Allergy Clin. Immunol. 2020, 147, 520-531. [CrossRef] [PubMed] 
122. Shields, A.M.; Burns, S.O.; Savic, S.; Richter, A.G.; Anantharachagan, A.; Arumugakani, G.; Baker, K.; Bahal, S.; Bermingham, W.; Bhole, M.; et al. COVID-19 in patients with primary and secondary immunodeficiency: The United Kingdom experience. J. Allergy Clin. Immunol. 2021, 147, 870-875.e1. [CrossRef]

123. McCaughan, G.; Di Ciaccio, P.; Ananda-Rajah, M.; Gilroy, N.; MacIntyre, R.; Teh, B.; Weinkove, R.; Curnow, J.; Szer, J.; Enjeti, A.K.; et al. COVID -19 vaccination in haematology patients: An Australian and New Zealand consensus position statement. Intern. Med. J. 2021, 51, 763-768. [CrossRef] [PubMed]

124. Ferretti, F.; Cannatelli, R.; Benucci, M.; Carmagnola, S.; Clementi, E.; Danelli, P.; Dilillo, D.; Fiorina, P.; Galli, M.; Gallieni, M.; et al. How to Manage COVID-19 Vaccination in Immune-Mediated Inflammatory Diseases: An Expert Opinion by IMIDs Study Group. Front. Immunol. 2021, 12, 656362. [CrossRef]

125. Choi, B.; Choudhary, M.C.; Regan, J.; Sparks, J.A.; Padera, R.F.; Qiu, X.; Solomon, I.H.; Kuo, H.-H.; Boucau, J.; Bowman, K.; et al. Persistence and Evolution of SARS-CoV-2 in an Immunocompromised Host. N. Engl. J. Med. 2020, 383, 2291-2293. [CrossRef]

126. Thompson, M.G.; Burgess, J.L.; Naleway, A.L.; Tyner, H.; Yoon, S.K.; Meece, J.; Olsho, L.E.; Caban-Martinez, A.J.; Fowlkes, A.L.; Lutrick, K.; et al. Prevention and Attenuation of Covid-19 with the BNT162b2 and mRNA-1273 Vaccines. N. Engl. J. Med. 2021, 385, 320-329. [CrossRef] [PubMed] 